The Aquatic Vegetation of the English Lakes

Author(s): W. H. Pearsall

Source: Journal of Ecology, Vol. 8, No. 3 (Dec., 1920), pp. 163-201

Published by: British Ecological Society

Stable URL: http://www.jstor.org/stable/2255612

Accessed: 27-06-2016 02:34 UTC

Your use of the JSTOR archive indicates your acceptance of the Terms \& Conditions of Use, available at

http://about.jstor.org/terms

JSTOR is a not-for-profit service that helps scholars, researchers, and students discover, use, and build upon a wide range of content in a trusted digital archive. We use information technology and tools to increase productivity and facilitate new forms of scholarship. For more information about JSTOR, please contact support@jstor.org.

Wiley, British Ecological Society are collaborating with JSTOR to digitize, preserve and extend access to Journal of Ecology 


\title{
THE AQUATIC VEGETATION OF THE ENGLISH LAKES
}

\author{
By W. H. PEARSALL.
}

(With thirteen Figures in the Text.)

\section{INTRODUCTION.}

Although the aquatic vegetation of most of the European lake areas has been studied, no description of the peculiarities of the English Lake Districts has yet appeared. In many respects, however, this lake area is most suitable for an investigation of this sort, for the lakes are of fairly uniform size, and lie in a small area on a relatively uniform series of rocks. It is the object of the present paper to give a general description of the plant communities of these lakes and to define, as far as data will permit, the habitat conditions in which these communities are found. In addition to these descriptions it will also be necessary to discuss the general conditions affecting life in these lakes in so far as they bear on the characters and distribution of the vegetation.

While the writer has been in intimate contact with three of the lakes for the last fifteen years, the work on which this account is based was started in 1913, and continued, with considerable interruption, until 1920. During this period many thousands of soundings have been taken in surveying the lake shores, a labour only possible through the unsparing assistance of my father, to whom I am greatly indebted. In obtaining data as to the habitat conditions, considerable difficulty has been experienced on account of the absence of any form of laboratory accommodation. To this must be ascribed the limitations which the data present.

The cost of the investigation has been defrayed in part by grants from the Royal Society.

\section{Methods.}

All of the methods employed have been described, and so will need brief reference only in this paper.

In surveying a portion of a lake shore, soundings were taken at known intervals along a line fixed by reference to the 6 in. O.S. Depths were recorded for each sounding in feet, the nature of the bottom (stony, sandy or muddy), the plants present and their relative abundance as brought up on the hooks of the dredger were noted. A series of sections of the area under survey could thus be obtained, and the details filled in by additional scattered soundings if required. Most of the maps appended are based on two such surveys, at least (Pearsall, 12). In mapping it is advisable to have a cord of known length attached to the shore to fix the position of the end of a section. In bays, a buoy was used for this purpose.

Journ. of Ecology VIII 
Soil samples were taken of the surface muds not exceeding a depth of $15 \mathrm{~cm}$. The only apparatus successful in getting the finer semi-liquid muds was an iron tube $(60 \times 7 \mathrm{~cm}$.), closed at the upper end, except for water outlets, and possessing a ball at the lower end, which normally closed the constricted mouth of the tube. When the tube struck mud, the latter was forced in past the ball which was only free to move about $10 \mathrm{~cm}$. up the tube, its further progress being stopped by a pin. On withdrawing the tube, the ball fell back to its place at the mouth, thus enclosing a quantity of mud within the tube.

The organic matter in such samples was determined as loss on ignition, and the mechanical analysis conducted to the English scale (Russell, 14), only the fractions sand, silt, and fine silt being determined. The fine gravel and clay fractions were generally negligible and hence were not separately estimated.

Potassium and phosphates were extracted with 10 per cent. citric acid, "available" potassium being determined by the perchloric acid method, and phosphates with ammonium molybdate (see Russell, 14). Nitrates were estimated by reduction with a zinc copper couple (Russell, 14). Owing to the fact that estimations had to be made two or more days after the sample was taken, the nitrate figures given are only indicative of the presence or absence of nitrifying organisms.

The dissolved gases were expelled by boiling, and estimated gas-volumetrically, carbon dioxide being absorbed by potash and oxygen by pyrogallol. The probable presence of peaty matter in the water rendered the usual alkaline titration methods uncertain.

Subaqueous light intensities were determined by the potassium iodide method (Pearsall, 1 2). This consists essentially in the liberation of iodine from potassium iodide and sulphuric acid, when exposed to light, the iodine being estimated by titration with $\frac{N}{10}$ potassium thiosulphate solution.

The complete water analyses given were performed by Messrs A. W. Richardson and R. Jaffe, of Bradford, to whom my thanks are due. All of the data given here, are for the vegetative period, June to September, unless otherwise stated. Considerable care was taken to get data representing the normal summer conditions in these lakes. Thus the water samples were taken with the lakes at normal summer level and after a week's fine weather.

\section{Physical Features.}

The English lakes lie in a small area of hilly country in Cumberland, Westmorland and Lancashire, about 30 miles $(48 \mathrm{~km}$.) in diameter, and including eight summits of over $900 \mathrm{~m}$. and about fifty of over $600 \mathrm{~m}$. The hills radiate like the spokes of a wheel from a common centre, and the lakes are situated in the long, narrow valleys between them.

Only the twelve largest of these lakes are considered in this paper, and these vary in size from Windermere $(16 \mathrm{~km}$. in length, mean breadth $.88 \mathrm{~km}$.) to 
Buttermere (length $2 \cdot 0 \mathrm{~km}$., mean breadth $\cdot 54 \mathrm{~km}$.). Little attention has been given to Thirlmere, now a reservoir, with varying water level and scarred shores. Seven lakes have over 50 per cent. of their area of greater depth than 20 m., but Esthwaite, Bassenthwaite and Derwentwater barely exceed this depth.

The lakes vary in altitude from Windermere, 41 m., to Hawes Water, $213 \mathrm{~m}$., but although they are low lying the surrounding country is little cultivated and is chiefly used as pasturage for sheep. The lakes lie in glacial rock basins, and glaciation has also left most of the surrounding district in a rocky condition, though it is locally strewn with morainic stones or glacial clays and loams. A good deal of the uniformity of the lakes can doubtless be attributed to the constant character of these deposits, but equally important is the similarity in physical characters of the underlying rocks, which are a series of slates, flags and grits of Silurian age. The rocks are non-calcareous and hard, and they weather very slowly. There are also occasional masses of granite, but these seem to have little effect on the lakes.

\section{Chemical Characters of the Waters.}

The waters draining from these rocks and surface deposits are singularly pure, containing only $\cdot 03-\cdot 07$ gms. per litre of dissolved matter. They are usually clear, but in two lakes, Bassenthwaite and Esthwaite, the waters are coloured with peaty matter. Their chief characters can be gathered from the following figures, which are the means for the waters of all the lakes:

\begin{tabular}{|c|c|c|c|c|c|c|c|c|c|c|}
\hline \multicolumn{2}{|c|}{ Total Residue } & alkalies & & & & & & & & \\
\hline Mineral & Organic & $\begin{array}{l}\mathrm{Na}_{2} \mathrm{O} \\
\mathrm{K}_{2} \mathrm{O}\end{array}$ & $\mathrm{CaO}$ & $\mathrm{MgO}$ & $\begin{array}{l}\mathrm{Fe}_{2} \mathrm{O}_{3} \\
\mathrm{Al}_{2} \mathrm{O}_{3}\end{array}$ & $\mathrm{CO}_{2}$ & $\mathrm{SO}_{3}$ & $\mathrm{Cl}_{2}$ & $\mathrm{SiO}_{2}$ & $\mathrm{NO}_{3}$ \\
\hline $45 \cdot 3$ & $8 \cdot 3$ & $10 \cdot 6$ & $5 \cdot 7$ & $2 \cdot 8$ & .05 & $5 \cdot 2$ & $11 \cdot 2$ & $7 \cdot 6$ & $2 \cdot 4$ & $\cdot 6$ \\
\hline
\end{tabular}

The most striking feature of these figures is the scarcity of lime and of carbonates, which results in the proportion of alkalies being relatively high, a most unusual character in pure natural waters.

Botanically, their most interesting features are the scarcity of nitrates (not detected in five out of the twelve lakes, and usually present only in traces), and the apparent absence of phosphates, which have not been detected at all.

These chemical characters of the waters are suggestive when considered in relation to the types of vegetation observed, for the larger free floating plants (Lemna, Stratiotes, etc.) are entirely absent from this lake area, a condition probably due to the scarcity of the essential plant foods in the water. Similarly, the phytoplankton is of relatively small bulk (West, 19), a fact probably related to the same condition.

The potash content of the waters is also often very small. The lowest concentration of $\mathrm{K}^{*}$ recorded as suitable for growing plants to a "satisfactory maturity" is seven parts per million (Cameron, 5). Yet the waters of 
Esthwaite and Ullswater, which contain the most luxuriant vegetation of any of these lakes, possess only two parts per million of dissolved $\mathrm{K}^{\circ}$. The evidence suggests, therefore, that the chemical characters of the waters limit the development of free floating vegetation and that the rooted vegetation probably depends on the soil rather than on the surrounding water for its mineral supplies. This suggestion will be examined further at a later stage.

\section{Subaqueous Light Conditions.}

Other factors may, however, be assumed to affect the distribution of vegetation in lakes, and of these light intensity is commonly supposed to be very important. The diminution of light in passing through water is at first extremely rapid in these lakes, but at greater depths is rather slow and the resultant light intensity (L.I.) at any depth, depends not only on the thickness of the layer of water, but also largely upon the amount of matter suspended in it, and to a less degree on its colour and the substances dissolved. The latter probably affect the coefficient of absorption, while suspended particles act more or less as a screen and also scatter light in all directions. Thus though direct light does not penetrate far, scattered diffuse light appears to travel downward for a considerable distance. The quality of the light is also assumed to change in this process, the rays of least wave length being least absorbed. There must ultimately result a L.I. so low or of such a quality that plants are unable to assimilate sufficiently in it to balance destructive metabolism during the vegetative season. The L. I. has been determined experimentally by the iodide method on Esthwaite (Pearsall, 12) and on Ullswater, Derwentwater and Windermere. The three latter lakes gave results of the same order, represented graphically in Figure 1, and indicating the usual light conditions in the majority of these lakes. The rapid reduction of direct light is very noticeable, and conforms to the statement of Regnard (quoted by Magnin, $\mathbf{9}$ ), in that it shows that 60-90 per cent. of the light falling upon water is absorbed by the first metre.

The observations on L. I. were made during bright sunlight, and hence under most favourable light conditions. When the sky is overcast, L.I. in the water is low and reliable results cannot be obtained from the greater depths. Moreover, even on sunny days, the results obtained vary in a curious manner, indicating that the light may be cut off more or less, in deeper water perhaps by layers of water of different densities, such as have been recorded by Kindle (8). Hence submerged vegetation lives under very unfavourable conditions; light is often deficient, and the days are relatively short. The curves given (Fig. 1) for the light intensities at any depth are probably, therefore, maximal. They must represent very inadequately the total amount of light energy falling on places at different depths during the growing season. Proportionately, this would be very much higher in shallow water and probably much lower in deeper water. As to seasonal variations in light, no data exist 
for this district, but taking into account the fact that maximum sunshine is in May and June in N.W. England it seems probable that light conditions are best at that time. In order to determine the relation of light intensity to the limit of vegetation, use was made of the fact that a $7 \mathrm{~cm}$. white disc, when lowered into the water, became invisible at a depth $1 \mathrm{~m}$. less than that at which a L.I. of 2 per cent. was found in the four lakes where the L.I. was determined.

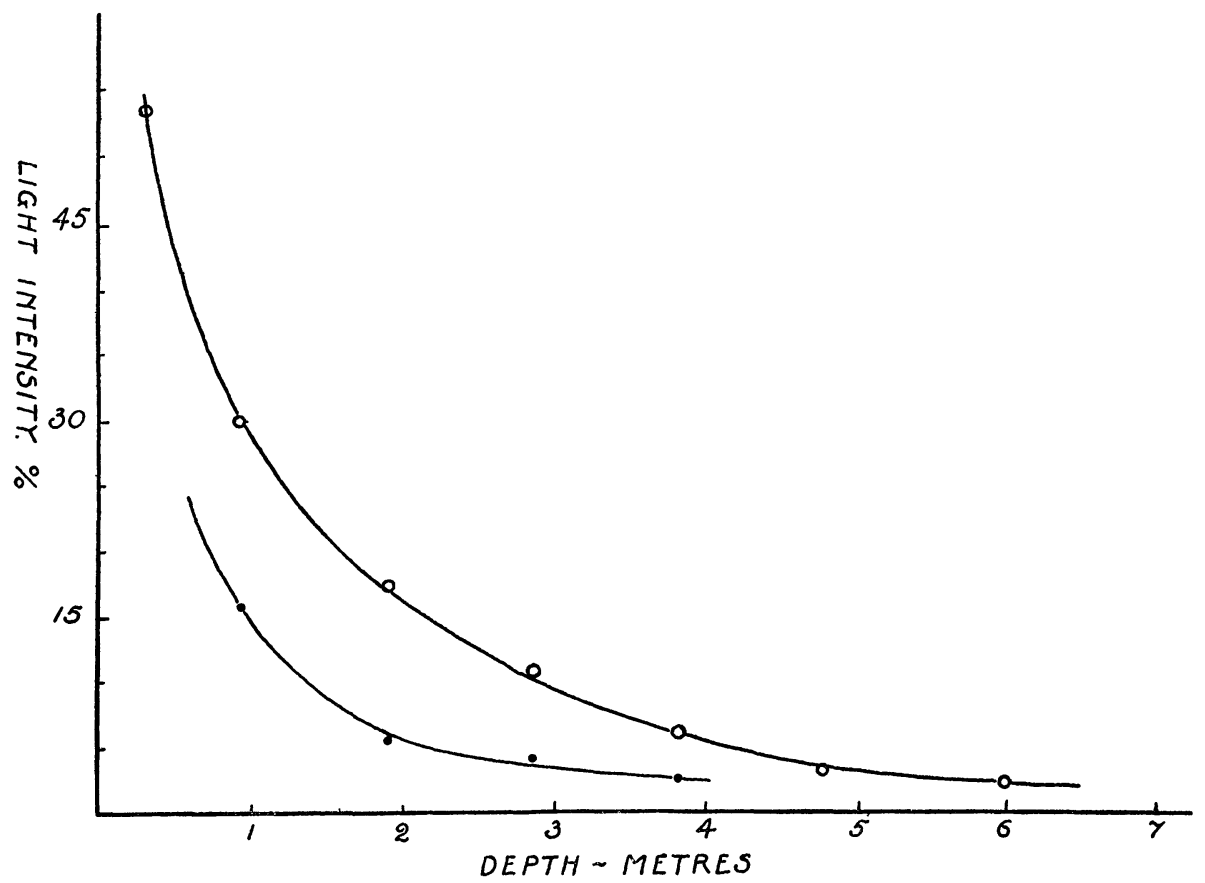

FIs. 1. The decrease of light intensity with depth during bright sunlight. Upper curve for Ullswater, Windermere and Derwentwater. Lower curve for Esthwaite.

By using this disc in all the lakes, the approximate depth at which a L.I. of 2 per cent. existed was found. The greatest depth at which vegetation normally occurs was determined in each lake from the sounding records, and the results so obtained are compared below.

$\begin{array}{lcc} & \begin{array}{c}\text { Depth at which } \\ \text { L.I. 2\% exists }\end{array} & \begin{array}{c}\text { Limit of } \\ \text { vegetation }\end{array} \\ \text { Wastwater } & 10 \mathrm{~m} . & 7 \cdot 7 \mathrm{~m} . \\ \text { Ennerdale } & 9 \cdot 3 & 8 \cdot 3 \\ \text { Crummock } & 9 \cdot 0 & 7 \cdot 1 \\ \text { Coniston } & 6 \cdot 4 & 5 \cdot 5 \\ \text { Hawes Water } & 6 \cdot 8 & 6 \cdot 8 \\ \text { Derwentwater } & 6 \cdot 5 & 6 \cdot 5 \\ \text { Bassenthwaite } & 3 \cdot 2 & 3 \cdot 0 \\ \text { Windermere } & 6 \cdot 5 & 6 \cdot 5 \\ \text { Ullswater } & 6 \cdot 4 & 6 \cdot 2 \\ \text { Esthwaite } & 4 \cdot 1 & 4 \cdot 0\end{array}$


It will be noticed that in six of the cases cited the lower limit of vegetation coincides very closely with a L. I. of 2 per cent.; in the remaining lakes, however, vegetation does not reach this L. I. These facts suggest that other conditions are concerned in the depth distribution of vegetation, but they certainly permit the assumption that the normal development of submerged plants cannot take place in L.I. of less than 2 per cent. The depth at which this L.I. occurs may therefore be termed the light (or photic) limit.

Occasional plants are sometimes found in greater depths, while very often vegetation in any of the lakes may cease considerably above the light limit. No evidence exists, for this lake area, which suggests that these variations are in any way connected with the light conditions.

The depth distribution of the individual species shows similar variations, but it is possible to distinguish two main groups of plants (see p. 182)-those normally abundant in shallow water and L. I. of 10 per cent. or more, and those also or entirely abundant in deeper water. Since light decreases rapidly in passing through water, it is possible that light conditions limit the former group to shallow water; there are, however, other factors which are found to operate in the same direction in relation to depth.

Were light conditions the predominant factor in the distribution of the aquatic vegetation, and if each species possessed a characteristic light requirement, we might expect the vegetation to be arranged in a definite series of depth zones parallel to the shore and of fairly uniform composition. A certain amount of zonation does exist in these lakes, but it bears no constant relation to the light conditions. In Derwentwater, which is a fairly typical lake, one often observes a zonation of this sort:

$\begin{array}{ll}\text { Littorella } & 0-2 \mathrm{~m} . \\ \text { Isoetes } & 2-4 \mathrm{~m} . \\ \text { Nitella } & 4-6 \mathrm{~m} .\end{array}$

Yet this is far from constant throughout the lake, and in Ullswater, Hawes Water and Windermere, with similar light conditions, the depths of the different zones are quite different. In Wastwater and Ennerdale, Isoetes and Nitella have almost exactly the same average depth (and light) range. In some cases, Nitella may be absent, in other cases, Isoetes, or as on the northern shore of Ennerdale, the Isoetes zone may be below the Nitella zone and the light conditions found in Derwentwater entirely reversed. Similar variations can be cited for most of the characteristic plants of the lake area, and they suggest most strongly that light conditions do not determine the distribution of the vegetation, except by imposing limits on the downward extension of species. The subsequent treatment of plant communities indicates these limits as far as it is considered possible to do so.

Other facts seem to favour the view that light conditions in these lakes are of secondary importance. The greater part of the vegetation exists at depths exceeding $2 \mathrm{~m}$., that is, in comparatively low L.I. Moreover, the lakes with 
the clearest waters contain the least vegetation, and those with more opaque waters contain more vegetation, in spite of the fact that they have a smaller area of shore-line within the light limit.

\section{Temperature Conditions.}

Other physical factors, such as temperature, may however be assumed to have some weight in determining the type of vegetation produced and in limiting its distribution. For the consideration of the temperature conditions in these lakes, use has been made of the scanty published data (Mill, 10, West, 19) and of a large number of personal observations. In addition, I am indebted to Mr C. Holme Lewis for the daily temperatures of the water (19171919) in the straining well at Thirlmere. All these results give general agreement as to the temperatures normally found in these lakes, and they are summarised below:

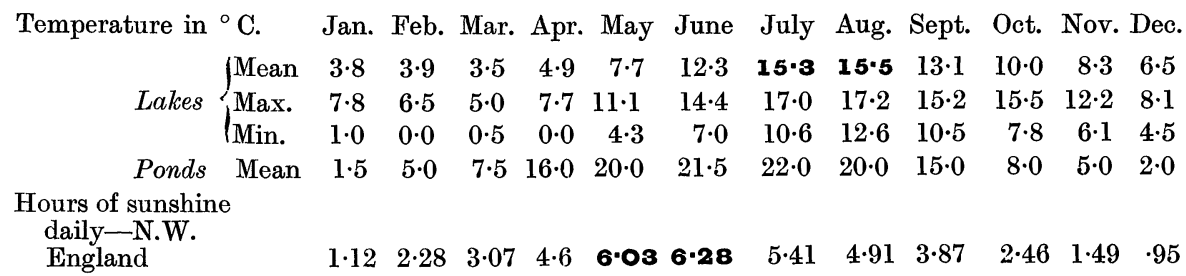

These figures can best be appreciated by comparing them with the approximate temperatures of ponds in the same region, during the same period.

While the water in these ponds is usually over $10^{\circ} \mathrm{C}$. from April to October (seven months) and over $15^{\circ} \mathrm{C}$. from May to September (five months), in the lakes these periods are shortened to five and less than two months respectively. Moreover, while the lake maximum is not often above $16^{\circ} \mathrm{C}$., the pond maximum usually reaches $20^{\circ} \mathrm{C}$. As a result of these differences, lake vegetation is altogether more tardy in development, and probably reaches its maximum about the end of August. For example, Ranunculus peltatus flowers in the lakes during August, in ponds about the end of May. Yet this is a shallow water plant in lakes, growing where temperature conditions are most favourable. The vegetative season of lake plants is, therefore, short and late, and it follows also that temperature is probably a limiting factor in the development of vegetation during the period of maximum sunshine, May and June. On these criteria also, we must probably regard the period mid-June to midSeptember (three months), as the normal duration of the vegetative season. Differences in temperature from lake to lake do not seem to be very great, no doubt due to the fairly uniform physical conditions. The shallower lakes are usually rather warmer in summer but the differences observed are small and rarely exceed $2^{\circ} \mathrm{C}$.

Temperature conditions also vary as the depth of the water changes. Magnin (9) indeed assumes that temperature limits the depth to which 
aquatic plants can grow in the Jura lakes. In the lake area under consideration there are, however, no grounds for such an assumption.

It is well known that wind action causes a continuous movement of surface water on to an exposed shore. This water returns below the surface as a drift at varying, but not extreme, depths (Wedderburn, 1 7). Thus the surface

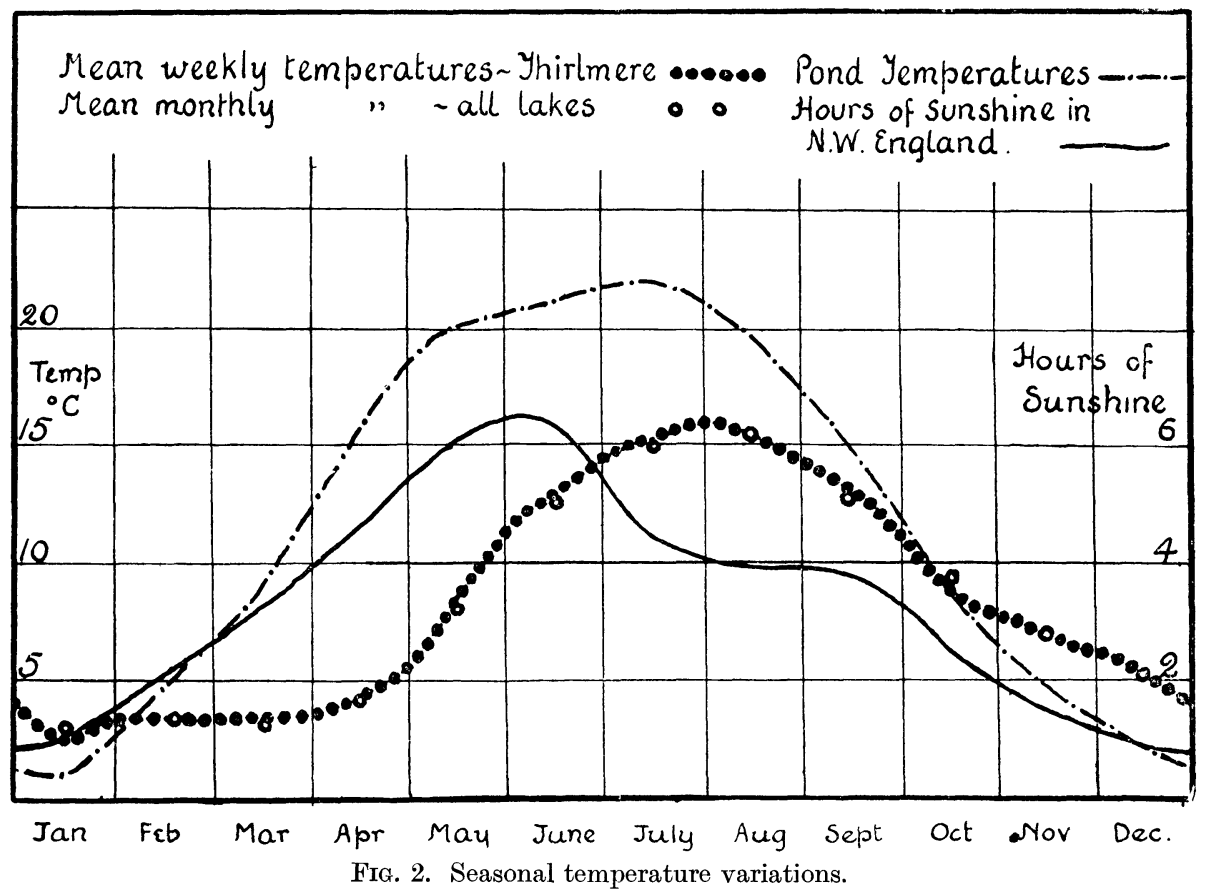

layers of water are mixed, and remain at fairly uniform temperatures. In Ullswater, for example, during the period August 1-20, 1919, the daily temperatures at $1 \mathrm{~m}$. and those at $6 \mathrm{~m}$., differed by less than $2.5^{\circ} \mathrm{C}$. (observed once on a hot calm day), the mean difference being only $\cdot 6^{\circ} \mathrm{C}$. In Windermere, two days in July, 1914, the mean temperature at $1 \mathrm{~m}$. was $16 \cdot 1^{\circ} \mathrm{C}$., while at $6 \mathrm{~m}$. it was $16 \cdot 0^{\circ} \mathrm{C}$. Wedderburn (1 7) records results for Loch Garry, June $6-20,1908$, in which the mean temperature at the surface was $12 \cdot 4^{\circ} \mathrm{C}$., that at $25 \mathrm{ft}$. was $11 \cdot 2^{\circ} \mathrm{C}$. Yet in the beginning of this period the temperature gradient was steep, as it was only then approaching the normal summer condition. Other results to the same effect are numerous, and it would appear that during the short summer season, temperature does not vary greatly within the surface $10 \mathrm{~m}$. of water. Since the photic zone for rooted plants is at most $10 \mathrm{~m}$. and is usually less than $7 \mathrm{~m}$., water temperature is not likely to limit the downward extension of vegetation, a conclusion directly opposed to that of Magnin (8) already quoted.

In shallow or land locked bays, it is quite possible to find locally much higher temperatures, but bays of these types are rare in the English lakes. 
There remains the possibility of the lake muds being heated by direct radiation. No evidence exists in support of this supposition, if the surface muds to a depth of $1.3 \mathrm{~m}$. be excluded. Below that depth the muds are usually at approximately the same temperature as the lake water, during the summer. The diathermancy of water is apparently less for dark than for light rays (Soret, 15), and Melloni (in 1 7) found that only 11 per cent. of the heat rays was transmitted through a layer of distilled water $9 \cdot 21 \mathrm{~mm}$. thick, using an Argand lamp as a source of heat. Wedderburn (1 7), using a Callander recorder and bolometer in Loch Ness, found that the difference between sunshine and cloud was indistinguishable at depths of less than $5 \mathrm{ft}$. $(1.5 \mathrm{~m}$.), while the difference between day and night could not be detected at depths exceeding $15 \mathrm{ft}$. (5.4 m.). The limit of vegetation in Loch Ness is about $30 \mathrm{ft} .(9 \cdot 2 \mathrm{~m}$.), and the water opacity is therefore comparable to that of our clearest lakes. Heat rays do not, therefore, penetrate far into the water, especially when the water is opaque as in this district. Hence it is that lake muds tend to have temperatures like those of the waters which bathe them, and it is very improbable that the temperature conditions limit the depth at which rooted plants can live. The temperature conditions among floating leaves and reedswamp plants, are, on the other hand, often much more favourable, especially if the place be well sheltered. These are considered at a later stage (p. 197).

\section{Aeration.}

Closely connected with the question of temperature is that of aeration, for the result of increasing temperatures is to decrease the solubility of the dissolved gases, a process which may result in loss of efficiency by living organisms. The results obtained are not numerous enough to be more than indicative, yet they point to very important changes in the dissolved gases, during the growing season.

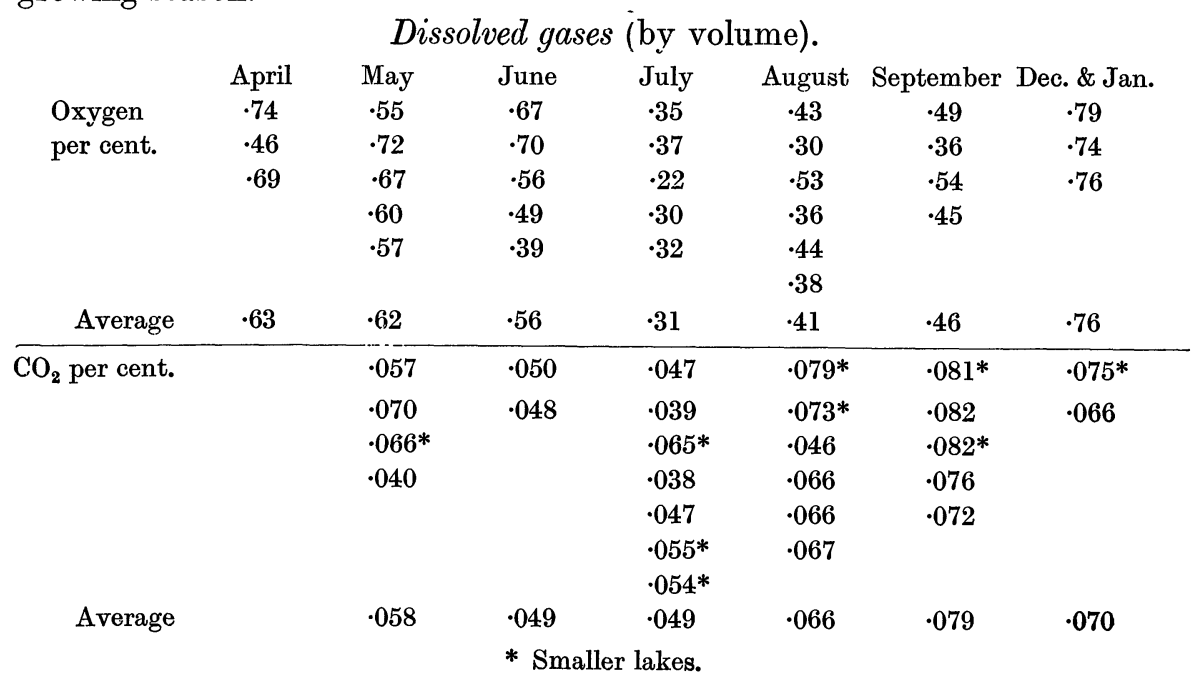


The oxygen content seems to be normally high, but falls off quite markedly in July to about 50 per cent. of saturation, and then rises again more slowly to its former level. Aeration is, then, at its worst when vegetation is developing most rapidly. The rise in $\mathrm{O}_{2}$ content in August and September is due probably to photosynthetic activity by plants, perhaps also to increased rainfall. The marked decrease in July, on the other hand, may apparently be connected with rising temperature and increased oxidation of organic matter.

Since waters for analysis were always taken near the outfall of the lake, the oxygen values given may be regarded as minimal, as there is some loss of $\mathrm{O}_{2}$ by oxidation during the passage of water through a lake. These lakes must, therefore, be considered to be well aerated, a conclusion which can be based also upon the continual movement and exposure to air of the surface layers of water.

Dissolved carbon-dioxide is apparently also dependent upon the season, as there is a tendency for this gas to be less abundant in the earlier part of the summer. The increase in August and September is probably due to increased oxidation consequent upon the temperature maximum in August, but there are obviously many variable factors of which we know nothing. It is of interest to note, however, that vegetation reaches its highest development after the temperature maximum, but when the $\mathrm{CO}_{2}$ content is highest. This is true both for rooted plants and also for the Desmid-phase of the plankton.

\section{The Relation of these Factors to the Distribution of Submerged Vegetation.}

The distribution of rooted vegetation must be assumed to be either dependent upon the characters of the surrounding waters or upon the characters of the lake floor. The necessarily brief review given above of the physical conditions of the habitats, indicates only one factor which varies with depth, viz. Light intensity, and which might conceivably be assumed to affect the distribution of aquatic vegetation. Apart from the objections already raised to light intensity as a determining factor, such a factor is clearly not adequate to explain differences in plant communities which exist at the same depth (and L.I.) and other factors must therefore be examined. If it be assumed that the properties of the lake waters primarily control the distribution of aquatic vegetation it must also be assumed that local concentrations of dissolved substances must occur. Such a hypothesis has been put forward by Brown (4) who suggests that distribution of submerged vegetation may be controlled by local concentrations of $\mathrm{CO}_{2}$. To test in practice the value of this hypothesis, water samples were taken at approximately the same distance $(.5 \mathrm{~m}$.) above divergent habitats bearing different plant communities. The gas content of these samples was determined, and below are given the $\mathrm{CO}_{2}$ values for samples collected in pairs on the same days. 


\begin{tabular}{cccccc}
\multicolumn{7}{c}{$\mathrm{CO}_{2}$ content (per cent.) } \\
Soil type & Plants & Windermere & Coniston & Esthwaite \\
& & June & Aug. & Sept. & \\
$5-15 \%$ humus & Potamogeton spp. & $\cdot 050$ & $\cdot 066$ & $\cdot 076$ & .055 \\
$15-30 \%$, & Isoetes or Nitella & $\cdot 048$ & $\cdot 067$ & $\cdot 072$ & .054
\end{tabular}

The figures show slight variations but these are not constant over the two types of plant community and soil examined. No constant local concentration of $\mathrm{CO}_{2}$ can be assumed to exist over the different habitats, and the type of plant growing in these habitats is clearly unconnected with the $\mathrm{CO}_{2}$ content of the water. Thus Brown's hypothesis need not be considered in this lake area.

Similar results were obtained for the oxygen concentrations, and no significant differences of $\mathrm{CO}_{2}$ or $\mathrm{O}_{2}$ content were found at different depths $(0-10 \mathrm{~m}$.). The latter result agrees with those of Bronsted and WesenburgLund (3) who found that in Furesö (Denmark) the dissolved $\mathrm{O}_{2}$ at $15-20 \mathrm{~m}$. was, during the summer, within about one-half per cent. of that at the surface.

These results are not surprising when it is remembered that the surface $15 \mathrm{~m}$. of water is normally in a continual state of circulation by wind (at any rate in the larger lakes such as are considered here). It must follow that the mixing action of these wind-caused movements will prevent the constant occurrence of local concentrations of any dissolved substances on the lake shores. From these considerations, we need not attempt to relate the distribution of the plant communities in a single lake to the characters of the lake waters.

It must, therefore, be concluded that the distribution of aquatic plants is controlled by variations in the composition of the lake shores and soils, and these must, therefore, now be considered.

\section{Soll Variations and their Origin.}

In the primitive condition most of the shores are composed of bare rock, screes or rounded morainic stones, but often they may be covered by glacial "till." Almost all the shores are now more or less modified by wave erosion, which forms a gravel wave cut terrace, just above and below the water level, the finer products of erosion being deposited in the deeper water. If waves are breaking obliquely on the shore-line, a littoral current is developed which sweeps along the shores, carrying the finer silts with it. When this current enters the deeper water of a bay, it slows down and drops the silt it carries. Thus bays, holes and sheltered shores tend to get silted up, while points, shallows and exposed shores are kept unsilted. As prevalent winds are S.W., most southern and western shores are comparatively silted, while northern and eastern shores tend to be silt free. Other factors, however, also play a great part in determining the amount of silting on a lake shore. Occasional storms from other directions than S.W., break up the normally sheltered shores and help to cover 
them with silt. Fluvial silts are equally important if abundant and sufficiently fine. They tend to cover all the shores of a lake, for silts once deposited are not removed by currents sufficiently strong to prevent their deposition. To these agencies, the modification of a rocky lake shore is due, and in general, the nature of the shore depends largely on the degree of exposure and the abundance of fluvial sediments.

It is convenient to recognise three main types of substrata:

(1) gravels and sands of wave-washed areas;

(2) unaltered stones or glacial clays;

(3) the deep-water, finer silts of littoral or fluvial origin.

These are, however, easily capable of further sub-division, especially when considered in relation to vegetation. On a typical exposed shore in Ullswater, for example, one finds

(1) bare loose gravel to $1.6 \mathrm{~m}$., Littorella on sand to $2.5 \mathrm{~m}$.

(2) Boulders washed clean to $3.5 \mathrm{~m}$.

(3) Thin silt on stones (with Isoetes) to $4.5 \mathrm{~m}$.; below this mud (with Nitella) to the light limit.

On a typical sheltered shore, zone 2 would normally be absent. Before the relations of vegetation to substratum are considered in detail, it is advisable to emphasise the point that most modified lake shores show distinct zonation of sediments. Water movements become less as the water gets deeper, consequently the substratum is composed of coarse materials in shallow water, and of increasingly fine particles as the water gets deeper.

\section{Silt and Vegetation.}

It must be clear that in rocky lakes, rooted vegetation will be confined to places where the substratum is softer, i.e. silted. Hence the first effect of silting is a physical one-the provision of a soft substratum. This may be illustrated by a diagram (Fig. 3) of Rampsholme, Derwentwater, an island lying off the exposed eastern shore and composed of morainic boulders. Wave action has kept the greater part of the shores of this island unsilted, but gravel has been carried to the N.E. forming a well marked spit, and the finer products of erosion have been deposited in deeper water along the same line, modifying the subaqueous contours very considerably. On this bank of silt, two plant communities occur, of Isoetes lacustris and Nitella opaca respectively. Their distribution in relation to the line of maximum silting seems to indicate also that another factor, the rate of silting, is in operation, and that Nitella grows where silting is most rapid, Isoetes where it is slow. The fact that the distribution of Nitella usually coincides with the presence of deep mud while Isoetes occurs on thin muds bears out this indication.

On an exposed shore-line (e.g. Scarfclose Bay, in the same lake) there are practically the same conditions, a gravel wave-formed spit, silts deposited in its shelter, and on these silts, Isoetes and Nitella, the latter in deeper water 


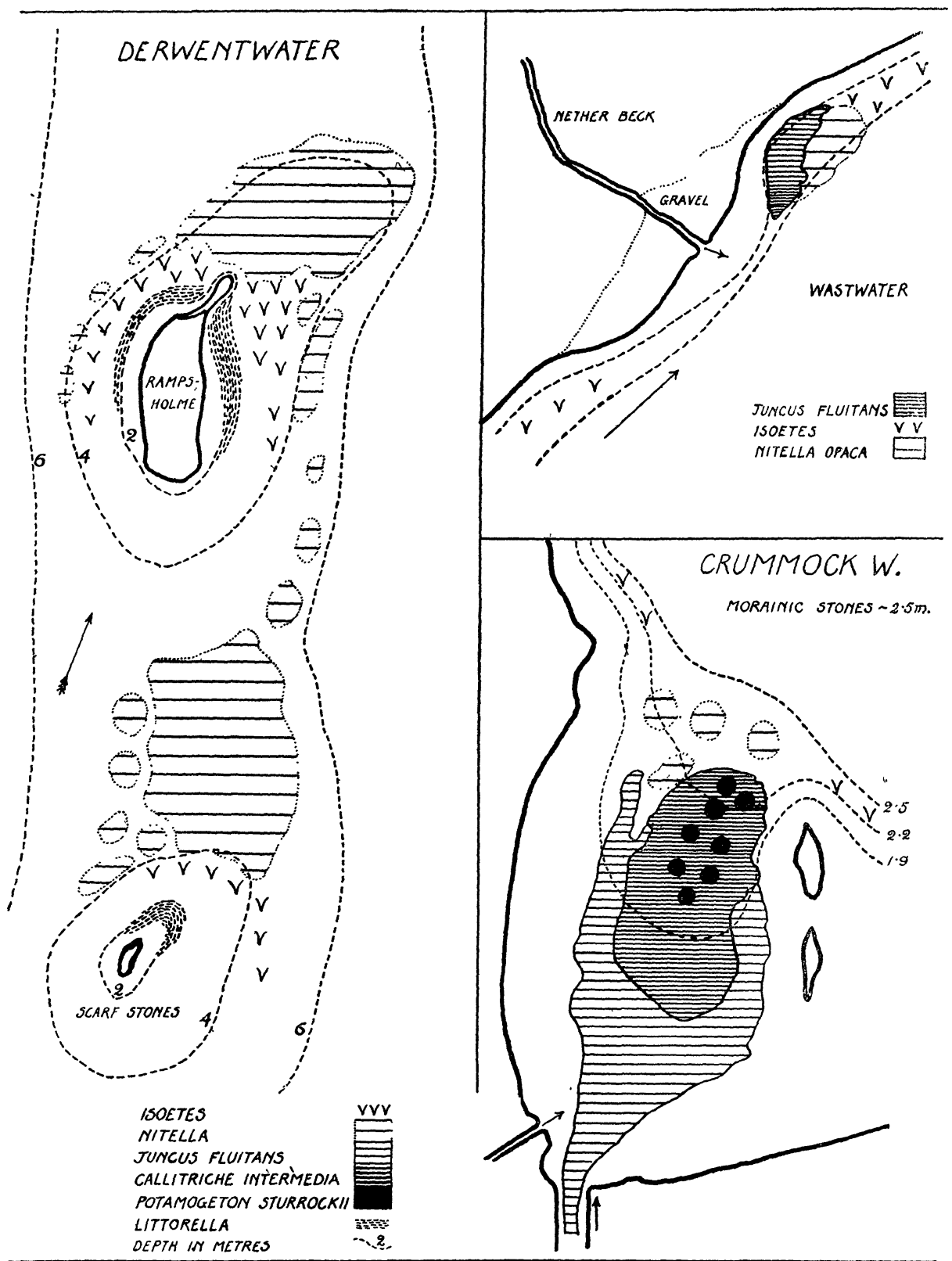

FIGS. 3, 4 and 5. Distribution of vegetation in relation to silting effects (see text).

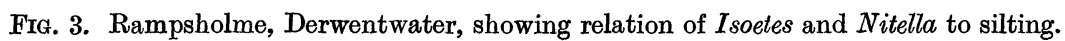

Fro 4. Outlet of Nether Beck, Wastwater, showing zonation of Juncus fluitans, Nitella and Isoetes in relation to silting.

Frg. 5. Stream outlet in Crummock Water, showing zonation of Juncus fluitans, Callitriche intermedia, Potamogeton, Nitella and Isoetes in relation to silting. 
where silt is more abundant (Fig. 6). In the example taken Littorella lacustris, Potamogeton gramineus and Scirpus lacustris also occur in the shelter of the spit. These may be left for the present, though it is clear that they show a similar relation to silting. Similar silting effects are shown near the Nether Beck, Wastwater (Fig. 4), which is pushing out a gravel delta into the lake. Here, near the stream mouth, a third important plant community of Juncus supinus f. fuitans is dominant, while as one passes away to the north this is replaced by Nitella, and the latter in turn by Isoetes. Normal wave action being from the S.W., both silts brought in by the stream, and those washed off the gravel shallow at its mouth, must be deposited in the small bay to the north. Their abundance will decrease as one passes away from their place of origin, and hence it follows that $J$. fluitans is characteristic of more rapid silting than Nitella or Isoetes. The appearance and depth of the muds bear out this assumption, which apparently holds in this lake region, wherever these communities are found (see Figures 4 and 5). Taking as a contrast Grassholme, an island on the western shore of Windermere (Fig. 10, p. 187), I soetes and Nitella again occur in deep water. Where silt is deposited most abundantly from erosion, e.g. N. of the island and at the point B, Potamogeton spp. are dominant. The fact that in this lake, Potamogeton replaces Juncus fluitans as the community of most rapid silting, may imply that the former requires still more abundant silts than Juncus. If this alone were the habitat difference, one would expect in the Grassholme region to find Juncus fluitans in some or all of the places occupied by Nitella, and the latter replacing Isoetes. As this is not the case, it therefore suggests that there is a qualitative difference between the types of silts on which the two communities are found (Fig. 10).

An examination of a locality occupied by both Juncus and Potamogeton will be useful as suggesting a point of attack for the problems of their distribution. The stream flowing from Buttermere to Crummock enters the latter lake at the S.W. corner, which is partly cut off from the rest of the lake by two rocky islets to the east (Fig. 5). In this corner, on the silt brought in by the stream, there is a dense mass of $J$. fluitans, with Callitriche intermedia locally sub-dominant, and $P$. pusillus ${ }^{1}$ abundant in the deeper water farthest from the stream. The similar amounts of organic matter in the soils of Juncus and Potamogeton here do not allow us to suppose that either place is receiving much more silt than the other. It is clear, however, that as one passes from the stream mouth into deeper water, that there will be a gradation of sediments, the coarser ones (sands) being deposited first and the finer (silts) being carried into the deeper water. It is on the latter only that Potamogeton occurs, for while the Juncus mud has a fine silt fraction of only 7 per cent., the mud below Potamogeton contained a similar fraction of at least 14 per cent. Carrying this suggestion further, it is found that the Potamogeton normally occurs in deeper water than Juncus and hence, probably on silts with finer particles.

1 Named P. sturrockii in the diagrams, Figs. 5, 10 and 11. 
FIG. 6

FIG. 7

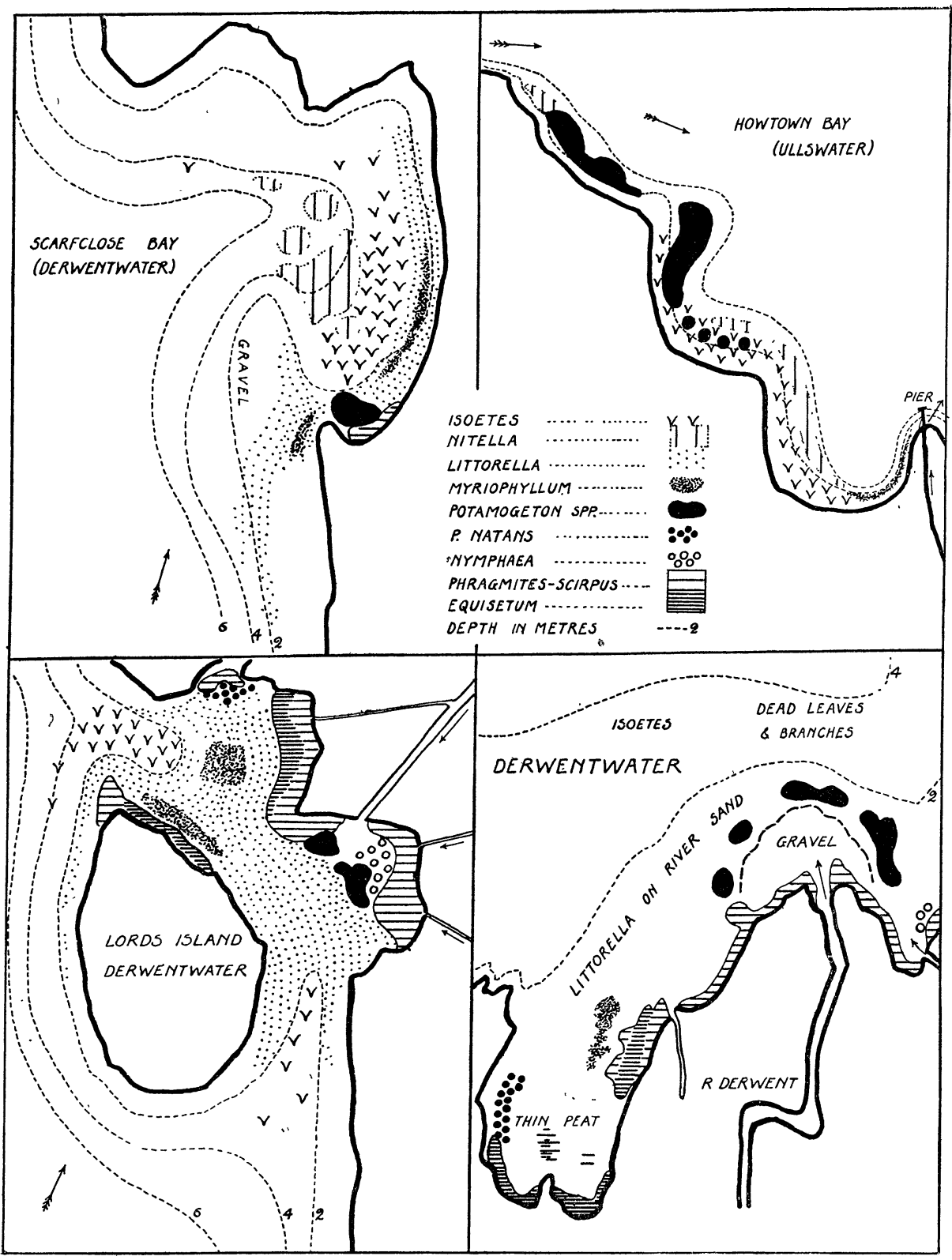

FIG. 8

FIG. 9

Figs. 6, 7, 8 and 9. Relation of plant communities to silting. Submerged Potamogeton spp., Nymphaea and Phragmites near sources of silt. P. natans, Myriophyllum and Equisetum away from silt sources. 
The examples considered above may be taken as illustrative of the methods used in considering the distribution of vegetation as recorded on maps. These examples, along with other evidence to be cited, give considerable support to the view that the silting factor underlies the distribution of all the types of aquatic vegetation found in this lake area, and that vegetation is only luxuriant in those places where silt is being deposited. But differences in the rate of silting or in the average size of the particles, do not seem wholly adequate to explain the presence of very numerous types of vegetation unless they can be considered in terms of their possible effects on plant growth.

\section{Analyses of Lake Muds in Relation to their Vegetation.}

Further analyses of a number of typical muds have therefore been made, in order to determine as far as possible:

(i) The effect of silting upon the chemical composition of the substratum.

(ii) The relation between the chemical composition of the silts and the sizes of their particles.

(iii) The relation between types of silt and the vegetation.

(i) To see if silting had an effect upon the composition of the substratum, muds were taken in pairs at the same depth, one from a silted and the other from a relatively unsilted habitat within the same area, e.g. a bay. The samples thus obtained are probably as nearly as possible comparable in every respect except the rate of silting.

Silts abundant

\begin{tabular}{|c|c|c|c|c|c|c|c|c|c|c|c|c|}
\hline Lake & 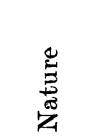 & 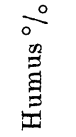 & 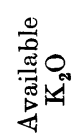 & 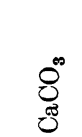 & 茕 & $\begin{array}{l}\stackrel{\infty}{\infty} \\
\underbrace{\infty}\end{array}$ & 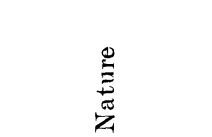 & 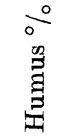 & 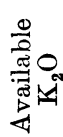 & $\begin{array}{l}\mathcal{D}^{\infty} \\
]_{0}^{\circ}\end{array}$ & $\stackrel{\circ}{\infty}^{\infty}$ & $\begin{array}{l}\stackrel{\infty}{+}^{+} \\
\mathbb{2}^{\infty}\end{array}$ \\
\hline Coniston & $\begin{array}{l}\text { Fine } \\
\text { mud }\end{array}$ & $17 \cdot 0$ & 338 & 90 & .85 & 54 & $\begin{array}{l}\text { Tough boulder } \\
\text { clay slight }\end{array}$ & $26 \cdot 0$ & 228 & 240 & .65 & 0 \\
\hline & Sandy & $34 \cdot 0$ & 292 & 100 & .71 & $22 \cdot 5$ & sandy silt & & & & & \\
\hline Ullswater & $\begin{array}{l}\text { Fine } \\
\text { mud }\end{array}$ & $13 \cdot 2$ & 336 & 280 & .94 & 29 & Boulder clay & $4 \cdot 2$ & 220 & 690 & .96 & 14 \\
\hline Esthwaite & $\begin{array}{l}\text { Semi- } \\
\text { liquid }\end{array}$ & $13 \cdot 7$ & 535 & 1000 & $3 \cdot 0$ & 49 & Thin silt & $15 \cdot 1$ & 342 & 1600 & $2 \cdot 4$ & $2 !$ \\
\hline Wastwater & $\begin{array}{l}\text { Rather } \\
\text { sandy }\end{array}$ & $34 \cdot 6$ & 260 & $*$ & $\cdot 28$ & * & Thin mud & $43 \cdot 0$ & 202 & $*$ & $\cdot 3$ & * \\
\hline Windermere & $\begin{array}{c}\text { Open } \\
\text { peat }\end{array}$ & $43 \cdot 5$ & 210 & 630 & $\cdot 8$ & 20 & Close peat & 68 & 153 & 620 & $\cdot 68$ & 19 \\
\hline Crummock & $\begin{array}{l}\text { Fine } \\
\text { sand }\end{array}$ & $25 \cdot 3$ & 260 & $*$ & $*$ & 16 & Thin silt & $7 \cdot 1$ & 210 & $*$ & $*$ & 4 \\
\hline
\end{tabular}

Figures in parts per million of dry matter.

* Not determined.

These figures show that silting has a pronounced chemical effect upon the substratum, increasing the proportions of potash and phosphates in the muds, and perhaps tending to increase the nitrate content also ${ }^{1}$. These substances are

1 Owing to the absence of laboratory facilities, nitrate determinations were made two days after the collection of the samples. They only indicate therefore the relative abundance of nitrifying organisms. 
of direct nutritive importance to plants. There may thus be a connection between the chemical effects of silting, and the greater luxuriance and abundance of vegetation upon silted areas. Such a view is, at any rate, not in disharmony with European views as to the meaning of soil analyses. There are, however, very definite signs that silting produces other effects upon the characters of the substratum. These effects are best seen by comparing the type of organic matter in silted soils with that where little silt is deposited. In the latter case, peaty matter accumulates-owing to the paucity of basesand often contains recognisable fragments of the plants which formed it, quite obviously decaying with extreme slowness. Where abundant silts are deposited, however, the organic content of the substratum is low (less than 20 per cent.), and the organic matter is very completely decomposed. It is possible to assume, in fact, that in the presence of silt (i.e. bases) organic decay is rapid and complete; in the absence of silt it is slow and incomplete. The greater "fertility" of silted soils is quite as probably due, according to our present knowledge, to the condition and rate of decay of the organic matter present, as to the greater quantities of nutritive substances (e.g. $\mathrm{K}_{2} \mathrm{O}$ ) present in the silted soils. Yet in either case, the ultimate source of this "fertility" of submerged soils can be attributed to the silting factor.

Among little silted soils there is the further possibility of distinguishing two extreme types, of which examples are given in the table. One of these types normally contains little organic matter and has not been long colonised by plants; the second type has a high organic content and represents the modification of the first soil type, due to vegetation. This latter type of soil possesses all the characters of an "acid" soil, a high proportion of undecayed organic matter, a high colloidal content, scarcity of bases, and an absence of aeration. Silting, by providing bases, prevents the development of this type of soil, so that in referring to unsilted and silted substrata, a distinction is, in fact, being made between soil types differing as do those of moor and fen respectively, though all intermediates between the two extremes exist.

(ii) The relation between the chemical and physical composition of the silts can be demonstrated by taking the potash contents as an indication of the chemical condition of the soils and comparing them with the mechanical analyses. Highly organic soils are excluded from this comparison.

\begin{tabular}{|c|c|c|c|c|c|c|c|c|c|}
\hline No. & Sand & Silt & $\begin{array}{l}\text { Fine silt } \\
\text { and clay }\end{array}$ & $\mathrm{K}_{2} \mathrm{O}$ & No. & Sand & Silt & $\begin{array}{l}\text { Fine silt } \\
\text { and clay }\end{array}$ & $\mathrm{K}_{2} \mathrm{O}$ \\
\hline 5 & $34 \cdot 2$ & $29 \cdot 3$ & 36.5 & .054 & 10 & $73 \cdot 4$ & $19 \cdot 2$ & $7 \cdot 4$ & .029 \\
\hline 7 & $69 \cdot 2$ & $14 \cdot 6$ & $21 \cdot 2$ & .046 & 13 & $71 \cdot 7$ & $14 \cdot 1$ & $14 \cdot 2$ & $\cdot 026$ \\
\hline 23 & 44.9 & $29 \cdot 1$ & $26 \cdot 0$ & $\cdot 041$ & 9 & $76 \cdot 6$ & $14 \cdot 0$ & $9 \cdot 4$ & $\cdot 023$ \\
\hline 20 & $51 \cdot 5$ & $28 \cdot 4$ & $20 \cdot 1$ & .037 & 15 & $82 \cdot 8$ & $15 \cdot 0$ & $2 \cdot 2$ & $\cdot 023$ \\
\hline 6 & $72 \cdot 0$ & $7 \cdot 6$ & $20 \cdot 4$ & $\cdot 034$ & 11 & $76 \cdot 8$ & $18 \cdot 0$ & $5 \cdot 2$ & $\cdot 023 b$ \\
\hline 8 & $64 \cdot 2$ & $23 \cdot 6$ & $12 \cdot 2$ & $\cdot 034$ & 2 & $63 \cdot 1$ & $16 \cdot 1$ & $20 \cdot 8$ & $.022 a$ \\
\hline 19 & 70.9 & $14 \cdot 1$ & $15 \cdot 1$ & .034 & 14 & $78 \cdot 0$ & $10 \cdot 9$ & $11 \cdot 1$ & $.021 a$ \\
\hline 12 & $65 \cdot 3$ & $24 \cdot 5$ & $10 \cdot 2$ & .030 & 16 & $75 \cdot 1$ & $14 \cdot 8$ & $10 \cdot 1$ & $.020 a$ \\
\hline
\end{tabular}

Figures as percentages. (a) Boulder clay with slight silt; (b) Slight silt over stones. 
These figures show that the finer silts tend to contain higher proportions of potash, the connection being most noticeable if the fine silt fraction is compared with the potash figure. Samples 2, 14, 16 represent the hard and compact boulder clays often found on little altered shores. Their paucity in potash is striking when they are compared with silts of similar physical composition.

Few, if any, of these samples showed any appreciable clay fraction.

It has been shown (cf. Russell, 14) that terrescrial soils in England normally have a potash content of about $\frac{1}{30}$ of the clay fraction. The relation shown by these silts is probably of a similar nature, though obscured, apparently by other factors, particularly the amount of organic matter present. Many of the muds contain little or no clay, and all tend to be relatively coarse even from the deeper parts of the lakes, a fact already remarked by Hutchings (7) for deep water deposits and also shown for Scottish lakes by the Scottish Bathymetrical Survey ( 11 ). If it is true for deep water silts, it should be much more so for littoral sediments, and it is therefore surprising to find deposits of the type of the first four samples in shallow water, in view of the constant water movements which exist there. On the other hand, most of these samples appear clayey when collected, and become more or less coherent when dry. These qualities are due, occasionally, to the packing of the finer grains, more generally to the presence of organic matter. Those muds richest in potash and finest are normally semi-liquid rather than clayey, when fresh, and after a few minutes exposure, begin to flocculate, leaving a layer of clear water on top. Though potassium cannot apparently be washed from them, when fresh, with water, this can be done after a few days' exposure, and consequent flocculation. Hence it is probable that they possess a considerable amount of matter in the colloidal state, which normally retains potassium by adsorption. It is well known that alkalies keep the typical electro-negative soil colloids in suspension, and it is thus possible that the greater proportion of potash present is the direct cause of the characteristic semi-liquid appearance of the finer muds. So far as present observations go, these fine semi-liquid silts are by far the most fertile type of lake muds. There is however no evidence which indicates that their greater fertility is due to chemical rather than physical characters, and it is probable that, as in terrestrial soils, the two groups of factors cannot be dissociated.

(iii) The relation of vegetation to chemical and physical characters of the soils may now be considered by taking the $\mathrm{K}_{2} \mathrm{O}$ content as indicative of the former and the fine silt and clay fraction as representing the latter and comparing them with the vegetation found growing where the sample was taken.

It seems clear from these results that there is a close relationship between the nature of the soil and the type of vegetation growing on it. Potamogeton spp. are quite definitely characteristic of the finer soils rich in potash, while Isoetes 
and Juncus fluitans occur on the coarser and poorer substrata. The previous suggestion that there was probably a qualitative difference in the muds on which Juncus and Potamogeton grow is thus borne out, and we are fully justified in assuming that the distribution of vegetation in relation to silting is due to the chemical effects produced by the silts deposited.

\begin{tabular}{|c|c|c|c|c|}
\hline Plant community & $\begin{array}{l}\text { Fine silt } \\
\text { and clay }\end{array}$ & $\begin{array}{l}\text { Mean } \\
\text { fine silt }\end{array}$ & $\mathrm{K}_{2} \mathrm{O}$ & Mean $\mathrm{K}_{\mathbf{2}} \mathrm{O}$ \\
\hline Naias d. & $46 \cdot 5$ & & - & \\
\hline Naias d. $P$. pusillus a. & $36 \cdot 5$ & & .054 & \\
\hline$P$. pusillus $\mathrm{d}$. & $21 \cdot 2$ & & .046 & \\
\hline $\begin{array}{l}\text { P. obtusifolius } \\
\text { and Elodea ab. }\end{array}$ & $\{12 \cdot 2\}$ & $25 \cdot 2$ & .034 & .044 \\
\hline$P \cdot$ pusillus $\mathrm{d}$. & $\left\{\begin{array}{l}18 \cdot 5 \\
36 \cdot 8\end{array}\right.$ & & - & \\
\hline P. pusillus d. $P$. praelongus a. & $26 \cdot 0$ & & .041 & \\
\hline P. praelongus $\mathrm{d}$. & $20 \cdot 1$ & & $\cdot 037$ & \\
\hline $\begin{array}{l}\text { P. perfoliatus } \mathrm{d} . \\
\text { praelongus } \text { a. }\end{array}$ & $15 \cdot 1$ & & $\cdot 034)$ & \\
\hline$P$. perfoliatus $\mathrm{d}$. & $\left\{\begin{array}{l}20 \cdot 4 \\
10 \cdot 2\end{array}\right\}$ & $15 \cdot 2$ & $\left.\begin{array}{l}\cdot 034 \\
.030\end{array}\right\}$ & .033 \\
\hline Callitriche intermedia d. & $\begin{array}{r}16 \cdot 5 \\
7 \cdot 4\end{array}$ & & - & \\
\hline Juncus fluitans & & $12 \cdot 6$ & & \\
\hline $\begin{array}{l}\text { C. intermedia sd. } \\
P . \text { pusillus a. }\end{array}$ & $14 \cdot 0$ & & .026 & \\
\hline Juncus fluitans $\mathrm{d}$. & $\begin{array}{l}4 \cdot 3 \\
9 \cdot 4 \\
7 \cdot 4 \\
2 \cdot 2\end{array}$ & $7 \cdot 5$ & $\left.\begin{array}{c}- \\
.023 \\
.029 \\
.023\end{array}\right\}$ & .025 \\
\hline Isoetes lacustris & $\left.\begin{array}{r}5 \cdot 2 \\
20 \cdot 8 \\
10 \cdot 1 \\
11 \cdot 1\end{array}\right\}$ & $11 \cdot 8$ & $\left.\begin{array}{l}\cdot 023 \\
\cdot 022 \\
\cdot 020 \\
\cdot 021\end{array}\right\}$ & $\cdot 021$ \\
\hline
\end{tabular}

It is permissible to apply these results more particularly to the question of the zonation of plant communities along lake shores. The fact that sediments become finer as one passes into deeper water has already been remarked. There are distinct zones of silts of different composition along any typical lake shore, and since these differ also in chemical composition we are justified in assuming that the zonation of vegetation is a result of these differences in soil conditions (a fine example is mapped in Fig. 11, p. 188). On this assumption it is possible to explain the variations in zonation between one lake and another as being due to the effect of different degrees of wave action and of silting. Owing to these differences plant communities will be found growing at, different depths and L.I., not only in different lakes but also in different parts of the same lake.

It is hoped to discuss the variations shown between one lake and another in a subsequent paper. The evidence presented here points definitely to 
edaphic conditions as being the fundamental habitat factor in the distribution of submerged vegetation. It gives also considerable indirect support to the supposition that rooted aquatic plants derive their mineral nutrition chiefly from the soil, rather than from the surrounding water.

\section{The Plant Communities.}

The plant communities fall into two very natural groups, those found in deep and shallow water respectively, but these, like most natural groupings, are rather difficult to define with any precision.

1. The deep water communities are usually developed in light intensity of less than 15 per cent., but are often found progressing into shallower water. They characterise primitive or silted soils, and are typically absent from areas subject to erosion. The depth at which they occur depends on the degree of erosion and the abundance of fluvial silts. In Wastwater, for instance, they are normally found below $4 \mathrm{~m}$. This is a rocky lake in which silts are scarce. In Esthwaite, where fluvial silt is abundant, they reach to within $1 \mathrm{~m}$. of the water level.

2. The shallow water communities occur normally, not always, in L.I. of more than 15 per cent. They are found on soils which are now, or have been, subject to wave erosion, or else on soils developed from those of deep water through the accumulations of silt and vegetation. The greater number of the plants in these communities are partly emergent-like Phragmites stems or Myriophyllum flowers, or else capable of withstanding desiccation-like Littorella. (The deep water plants normally live entirely submerged in these lakes.)

The shallow water communities are not necessarily developed in succession to deep water plants: they also include communities colonising eroded shores.

For the nomenclature to be applied to these communities, reference should be made to Pearsall (13). Those described here, are assumed to be of equal rank, and to be equivalent to the consocies or associes of Clements (6). The frequencies used have a numerical basis, and are averages for all the lakes. In field work, only three frequencies are used, abundant, frequent, and occasional. As the number of plants brought up by a dredger is limited, these are given the numerical values of 4,2 and 1 respectively, and all the records for any one community are added together to give the approximate composition of the community as a whole. As in most of these communities the associates are local, it is considered that a better idea of relative frequency can be conveyed by symbols than by the numbers obtained in the above manner.

\section{Deep Water Communities.}

1. The Isoetes lacustris consocies occurs normally on stones, masked by a thin layer of silt, or on boulder clay (usually greasy and tough). On either of these habitats, Isoetes is usually the only plant, and often is but sparsely developed. It may also occur on sand, and sometimes on thin peat, if derived from one of the normal habitats of this community. The organic content of the 
soil is very variable, lying between 2 and 70 per cent. (mean, 25•0), the lower values being normally found on clay. Owing to the slow rate of growth and sparse distribution of Isoetes, peaty matter must accumulate very slowly, and the habitat conditions must also remain relatively constant over very long periods of time. The potash content of the Isoetes soils is low, and they are in most cases sterilised glacial deposits, normally unsilted. With increase of silting, the community becomes closed, and associates begin to appear. As Isoetes is apparently unable to alter its rooting level, it becomes covered by sediment and dies. During this process, young plants with one or two pairs of leaves are often very abundant, but they seem to be killed more easily than the older plants, perhaps because of their small reserves of food.

The light conditions under which the community grows cannot be regarded as determining its distribution in any way. The L.I. varies between 3 and 50 per cent., almost the greatest possible range.

The characteristic associates belong to two classes-those but slightly dependent on the substratum (e.g. Mosses and Utricularia) which are found where the soil is highly organic, and those species apparently dependent on silting (e.g. Nitella and Myriophyllum). The following are included in this consocies:

\begin{tabular}{|c|c|c|}
\hline Isoetes lacustris $\mathrm{L}$. & d & Utricularia neglecta Lehm. \\
\hline Nitella opaca Ag. & la & U. ochroleuca Hartm. \\
\hline N. flexilis Ag. & 1 & Fontinaīis antipyretica $\mathrm{L}$. \\
\hline Chara fragilis Desv. & $\mathrm{r}$ & Eurhynchium rusciforme Milde \\
\hline Potamogeton perfoliatus L. & 1 & E. praelongum Hobk. \\
\hline Sparganium minimum Fr. & $\mathbf{r}$ & Climaciumdendroides W. and M. \\
\hline Myriophyllum spicatum L. & la & Hypnum cuspidatum L. \\
\hline Ranunculus spp. & $\mathrm{r}$ & Mnium cuspidatum Hedw. \\
\hline
\end{tabular}

2. The Nitella associes develops in silted habitats where there is an accumulation of easily penetrable material. In composition this may range from fine sand to the finest muds, its potash content varying accordingly. The organic content is less variable, and never extreme, ranging from 8-35 per cent. (mean 18.4).

\begin{tabular}{|c|c|c|}
\hline Nitella flexilis Ag. & ld & Potamogeton pusillus L. subsp. \\
\hline N. opaca Ag. & d & $\begin{array}{l}\text { lacustris subsp. nov. }{ }^{1} \\
\text { crispus } \mathrm{I} .\end{array}$ \\
\hline Chara fragilis Desv. & o & P. crispus $\mathrm{L}$. \\
\hline C. fragilis sub sp. delicatula Braun. & la & Elodea canadensis Michx \\
\hline Isoetes lacustris $\mathrm{L}$. & 1 & Myriophyllum spicatum $\mathrm{L}$. \\
\hline Potamogeton praelongus Wulf. & 1 & M. alterniflorum D.C. \\
\hline P. perfoliatus $\mathrm{L}$. & $\mathbf{r}$ & Callitriche intermedia Hoffm. \\
\hline P. pusillus L. & $\mathbf{r}$ & Eurhynchium rusciforme Milde \\
\hline
\end{tabular}

The L. I. may range from the maximum to the minimum (2 per cent.), but the community is typical of deeper water, since only in such places can silt

1 A deep water subspecies characterised by its rounded leaf tips and the absence of semifloating leaves. It does not revert to $P$. pusillus type when grown under high light intensities. 
accumulate. Thus the typical light range would be 10 to 2 per cent., but it must be remembered that a soft substratum is a necessary and usually the limiting factor. The associates vary widely, as the community is in close contact with most of the deeper water communities throughout the series of lakes, and is the only plant community typical of all the lakes.

3. The Juncus fuitans consocies is scattered throughout the more rocky lakes, in well defined areas near the mouths of streams, where there is an abundance of coarse silt or sand. The water is usually rather shallow, generally about $3 \mathrm{~m}$., and the L.I. consequently high, and never less than $5 \%$, as apparently it is in Loch Ness (West, 38). One would not, in fact, expect a terrestrial plant to show the specialisation necessary for life in deeper water.

It has already been shown that the substratum tends to be richer in potash than that of Isoetes, but owing to its coarseness it is still relatively poor. The substrata are relatively inorganic ranging from $17 \cdot 5-35$ per cent. of organic matter, mean $26 \cdot 8$ per cent.

$J$. fuitans is also locally subdominant in shallow water, but with very different associates, usually Lobelia and Potamogeton natans. The characteristic feature of this second type of habitat is its peaty nature and high organic content (average 72 per cent., range $49 \cdot 1-91 \cdot 8$ per cent.). It is also remarkable for the lack of silt, and one soil of this type analysed ("close peat," p. 178) had the lowest $\mathrm{K}_{2} \mathrm{O}$ content recorded, though it should be noted that $J$. fluitans was no more than abundant in that instance. It seems probable, therefore, that these unsilted peaty soils possess the same essential characters as the coarser silts, and that these characters are closely connected with the scarcity of bases.

Callitriche intermedia is a fairly constant associate of $J$. fuitans, and may be locally sub-dominant, as in Crummock (Fig. 5) and in the outlet of Wastwater. A sparse and apparently vestigial community of this plant occupies large areas of the silted end of Bassenthwaite, off the Derwent inlet. The soil is composed of sand (see Table, p. 181) with about 20-25 per cent. of organic matter. Elsewhere Callitriche intermedia occurs with Potamogeton pusillus, and in Coniston it is being replaced by the latter. Apparently the Callitriche grows on soils intermediate between those of Juncus and of P. pusillus, but since it is rather local in distribution I have preferred to regard it as a socies of the $J$. fuitans community. Its intermediate habitat is, however, very well illustrated in Crummock (see Fig. 5). The list of observed species in the Juncus fluitans community is:

Juncus bulbosus L. f. fuitans
(var. Lam.)
Callitriche intermedia Hoffm.
Myriophyllum spicatum L.
M. alterniflorum D.C
Nitella opaca Ag.
N. flexilis $\mathrm{Ag}$.
Chara fragilis Desv.

Isoetes lacustris $\mathrm{L}$. $\quad \mathrm{f}$

d Potamogeton pusillus sub sp. f lacustris
1

f P. polygonifolius Pourr. var. pseudo fluitans Syme Utricularia intermedia Hayne 1 Fontinalis antepyretica L. $\quad \mathrm{l}$ 
4. In lakes where fine sediments are frequent, e.g. Coniston, Windermere, Ullswater and Esthwaite, Potamogeton pusillus replaces Nitella where silting is rapid. The soils become markedly rich in potash and rarely show signs of any undecayed plant remains, and they have, also, a lower organic content than those under Juncus fluitans (range 10-25 per cent., mean 16.7). On account of the fineness of the particles, such soils can only be deposited in deep water, and the community therefore grows in low L.I. (10-2 per cent.) and is the only one among the higher plants which lives entirely under such unfavourable light conditions.

The $P$. pusillus community is remarkable for the wide range of habitat conditions under which it is found, from the poor sands bearing $J$. fluitans to the very fine and rich silts found beneath Naias and its associates. Its edaphic requirements also overlap those of $P$. perfoliatus and $P$. praelongus. The community includes:

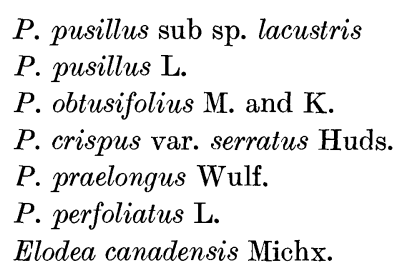

$\begin{array}{lll}\text { d } & \text { Callitriche intermedia Hoffm. } & \text { o } \\ \text { o } & \text { Myriophyllum spicatum L. } & \mathrm{f} \\ \mathrm{r} & \text { M. verticillatum L. } & \mathrm{r} \\ \mathrm{vr} & \text { M. alterniflorum D.C. } & \mathrm{r} \\ \text { l } & \text { Nitella opaca Ag. } & \mathrm{f} \\ \text { l } & \text { N. Alexilis Ag. } & \mathrm{l} \\ \text { lf } & \text { Isoetes lacustris L. } & \mathrm{l}\end{array}$

5. The Naias flexilis consocies is found, in Esthwaite only, growing on very fine semi-liquid muds, observed in no other lake. These muds are apparently also distinct in their low organic content (5-10 per cent., mean 7.3) and in their richness in potash (p. 181). Under these conditions Naias precedes $P$. pusillus, apparently usurping the role-normally filled by Nitella - of a colonising community.

Occasionally found with Naias flexilis R. and S., are P. pusillus L., P. panormitanus Biv. B., Hydrilla verticillata var. gracilis Casp. and Nitella flexilis.

6. The linear leaved associes, found only in Esthwaite, represents a development of the $P$. pusillus consocies, owing to the luxuriant silting conditions found in this lake. Silts are particularly fine and abundant and other linear leaved species become sub-dominant. The soils are like those beneath Naias, but contain higher proportions of organic matter (10-15 per cent., mean 13.7), see Pearsall (12).

The associated plants are essentially those of the $P$. pusillus consocies, but $P$. panormitanus Biv. B. and Callitriche autumnalis L. are sub-dominant, while Hydrilla verticillata var. gracilis (Casp.) and Elodea canadensis Michx. are frequent.

7. Since 1915, the Potamogeton obtusifolius consocies has developed in Esthwaite over considerable areas formerly occupied by the linear leaved community. It also occurs in Windermere, near the mouth of the Blelham 
beck, where it seems to be replacing the same species. The organic content of the soil is rather high (18--24 per cent., mean $21 \cdot 4)$; it is fine, and apparently rich in potash (p. 181).

$\begin{array}{llll}\text { P. obtusifolius } \text { M. and K. } & \text { d } & \text { Myriophyllum spp. } & \text { o } \\ \text { Callitriche autumnalis } \text { L. } & \text { I } & \text { P. alpinus } \text { Balb. } & \text { o } \\ \text { Sparganium minimum } \text { Fr. } & \text { f } & \text { P. pusillus } \text { sub sp. lacustris } & \text { r } \\ \text { Elodea canadensis Michx. } & \text { f } & \text { P. panormitanus Biv. B. } & \text { r }\end{array}$

The light range of communities 5, 6 and 7 is typically rather higher than that of the $P$. pusillus consocies, about $10-3$ per cent. The $P$. obtusifolius consocies has been observed elsewhere in L.I. of 20 per cent.

8 and 9. The consocies of Potamogeton perfoliatus and $P$. praelongus can best be discussed together. They are characteristic of the more silted lakes, e.g. Coniston, Windermere, Ullswater and Esthwaite, and occur in well silted places (see Figs. 10 and 11). P. praelongus grows in deeper water, on finer and more abundant silts than $P$. perfoliatus and consequently in lower L.I. While $P$. praelongus usually succeeds Nitella or $P$. pusillus, $P$. perfoliatus appears more often where silt is accumulating on the Isoetes habitat, though it may also succeed Nitella, $P$. pusillus, and Juncus fuitans. The habitat of $P$. praelongus lies within the habitat range of $P$. pusillus in all respects, but the former does not occur on the finer and richer silts, such as those found in the deeper water of Esthwaite. Just as very rapid deposition of sediment on fens apparently prevents the growth of trees (e.g. Salix and Alnus) and is accompanied by a vegetation of grasses (є.g. Phalaris and Calamogrostis), so, apparently, rapid subaqueous silting is accompanied by the growth of linear-leaved, rather than broad-leaved species of Potamogeton. If this assumption is true, consolidation and stabilisation of silts should be accompanied by the development of the larger species, a change observed to take place in fens. It is therefore significant to notice that $P$. perfoliatus, $P$. praelongus and $P$. alpinus (see below), are spreading in Esthwaite.

\begin{tabular}{lccccc} 
& $\begin{array}{c}\text { \% L.I. } \\
\text { (Normal range) }\end{array}$ & \multicolumn{2}{c}{$\begin{array}{c}\text { Org. content } \\
\text { of soil }\end{array}$} & \multicolumn{2}{c}{$\begin{array}{c}\text { Fine silt and } \\
\text { clay \% }\end{array}$} \\
& & Range & Mean & Range & Mean \\
$P$. perfoliatus & $30-5$ & $13-29(4)$ & $20 \cdot 3$ & $10-21$ & 15 \\
$P$. praelongus & $20-2$ & $10-21(4)$ & $14 \cdot 8$ & $15-26$ & 20 \\
$P$. pusillus & $15-2$ & $12-26(11)$ & $16 \cdot 4$ & $12-46$ & 23 \\
$P$. alpinus & $40-4$ & $20-44(4)$ & $33 \cdot 4$ & - &
\end{tabular}

These figures serve to indicate the overlapping ranges of three Potamogeton spp., and also the higher organic content of the coarser silts on which $P$. perfoliatus grows. The potash and fine silt fractions of $P$. pusillus soils also overlap with those of $P$. praelongus and $P$. perfoliatus. The figures for $P$. alpinus are for comparative purposes only. 


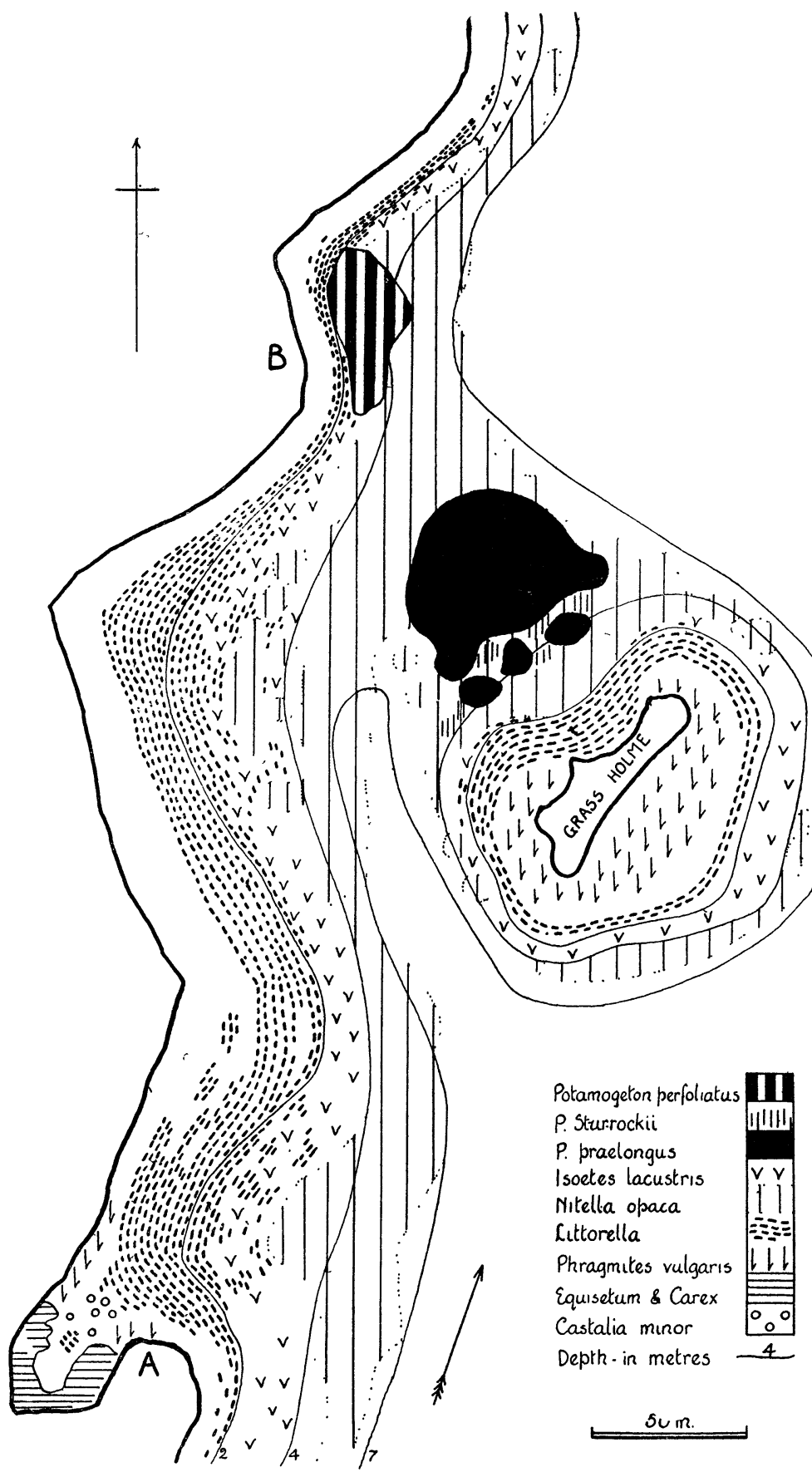

Fia. 10. Grassholme, Windermere, showing relation of Potamogeton to shelter and silting, also a closed bay with Castalia minor and Equisetum-Carex reedswamp. 
The following are typical associates of the two consocies:

8. Potamogeton perfoliatus d

including var. oblongifolius (Mert. and-Koch)

var. lanceolatus Blytt.

var. macrophyllus Blytt.
$P$. praelongus Wulf.
o
Chara fragilis Desv.
P. pusillus L. (agg.)
Elodea canadensis Michx
$P$. alpinus Balb.
Myriophyllum spicatum L. o
$P$. angustifolius Presl.
Isoetes lacustris L.
Nitella opaca Ag.
9. P. praelongus Wulf.
alpinus Balb.
$P$. pusillus $\mathrm{L}$.
Nitella opaca Ag.
Myriophyllum spicatum L. o
$P$. pusillus sub sp. lacustris o
Elodea canadensis Michx. 1
$P$. lucens $\mathrm{L}$.
$P$. perfoliatus L.

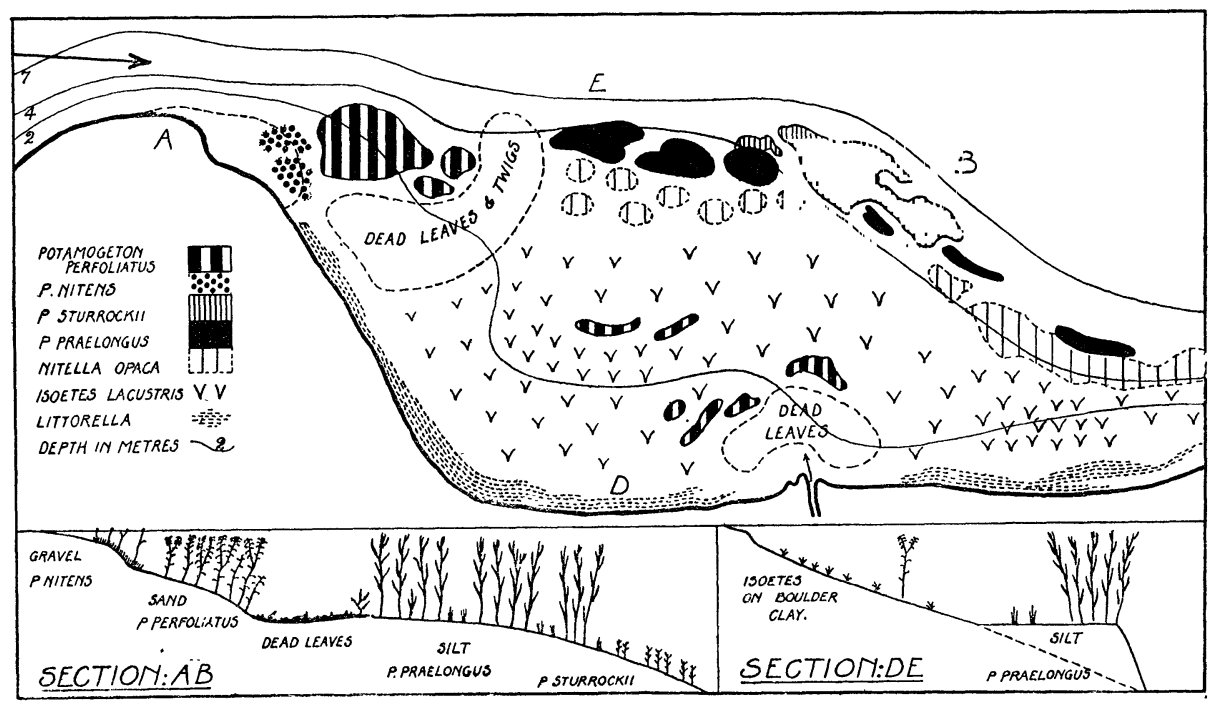

Frg. 11. Thwaite Hill Bay, Ullswater, showing silt zonation in relation to the distribution of Potamogeton spp.

10. The $P$. alpinus consocies succeeds $P$. praelongus or $P$. pusillus where silts are rich and very abundant. Normally, these conditions prevent the accumulation of organic matter, and since $P$. alpinus has only been observed on relatively organic substrata with a mean organic content of 33.4 per cent. (range 20-44 per cent.), it probably takes a very long time for the edaphic conditions to change in the necessary manner. The community has only been seen in Windermere, Esthwaite and Derwentwater, in each case on a long colonised soil among abundant vegetation. Characteristic species are:

Sparganium minimum Fr.

Potamogeton obtusifolius M. and K. 1

Elodea canadensis Michx. o

f

Nymphaea lutea L.

Myriophyllum verticillatum L. 1

M. spicatum $\mathrm{L}$. o 
11. The Sparganium minimum consocies is similarly one of organic soils, showing affinities to those of $P$. obtusifolius and $P$. alpinus. In its most typical form, it consists of scattered plants on an otherwise bare substratum, in deep water. As far as can be judged no other submerged plants are able to live, presumably owing to the character of the soil. Yet these places are nearly always being colonised by water-lilies, and they suggest that the cycle of submerged vegetation is over. As, however, other submerged plants can grow on soils containing far higher organic contents than some of these under Sparganium, which range from 24 to 96 per cent. (mean 44.7), explanation is certainly difficult, apart from the assumption that successive communities of plants make the soil toxic to themselves, and that Sparganium is very resistant to the changes produced. This community exists in Derwentwater, Coniston, Windermere and Esthwaite. It is entirely submerged and ranges from L. I. 4 to 40 per cent. Floating leaves are very rarely developed.

12. The Fontinalis antepyretica consocies shows no very definite relation to soil conditions or light intensity, but a decided preference for places near the mouths of streams. The soil is normally organic, but at times the community is developed, rather sparsely, on bare rocks. The associates are usually characteristic of the more organic communities. In Esthwaite, P. obtusifolius and Elodea are not infrequent. In Coniston and Derwentwater, Utricularia ochroleuca and $U$. neglecta, with Eurhynchium rusciforme, are frequent, while Sparganium minimum or Juncus fluitans is occasional. Eurhynchium praelongum has also been observed.

\section{Deep Water Plant Succession.}

Before dealing with the shallow water plants, it will be profitable to attempt to indicate the successions observed in deep water and to discuss briefly factors which may be correlated with these changes. Fig. 12 represents diagrammatically the successions observed. Each of the arrows in this figure corresponds to a known transitional community, the directions in which the arrows point indicating changes either recorded in the last years, or less often, assumed from consideration of soil organic content or silting relations. Reference has already been made to a few additional and less typical changes.

It will be noticed that three main types of plant succession are found:

(1) Along the line Isoetes, Juncus fluitans, Potamogeton natans. This is developed on coarse, potash poor and organic soils in rocky lakes.

(2) In the general direction Isoetes, large Potamogeton spp., to Castalia and $P$. natans, intermediate in soil characters and most typical of all the lakes.

(3) Naias, linear-leaved species, water-lilies. This is chiefly found in Esthwaite, and occurs only on the finest, richest and least organic silts. 
It is clear that these three types are chiefly distinct in the physiographic sense, since they depend on variations in the fineness and abundance of sediments.

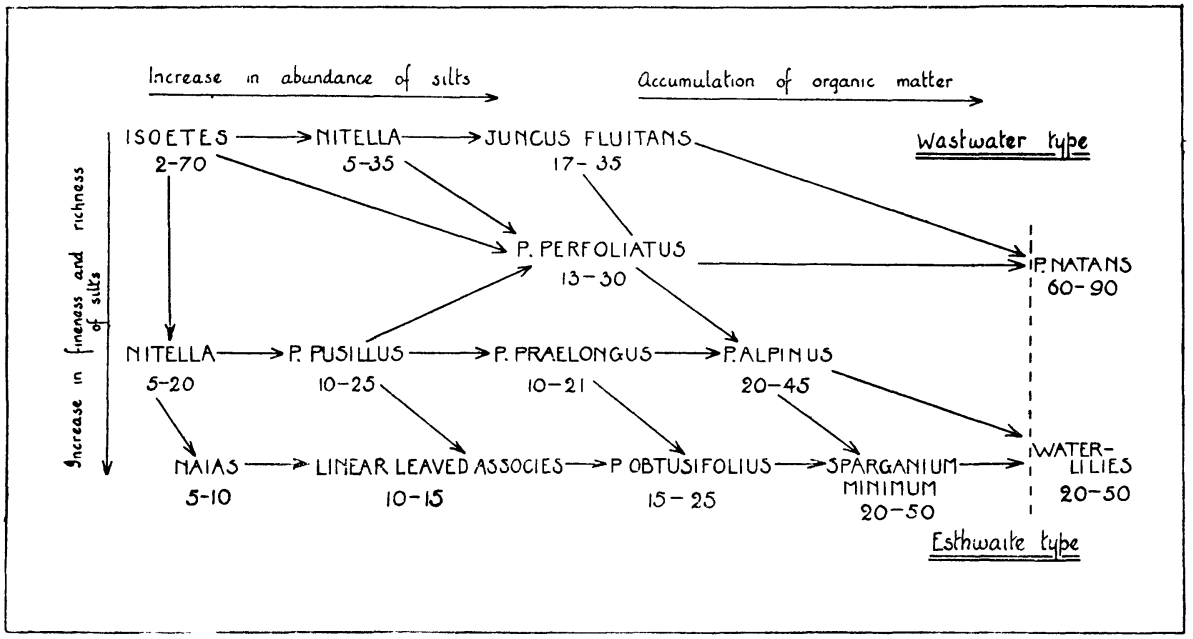

Fra. 12. Succession among deep water communities. The figures given indicate the percentage organic content of the soil.

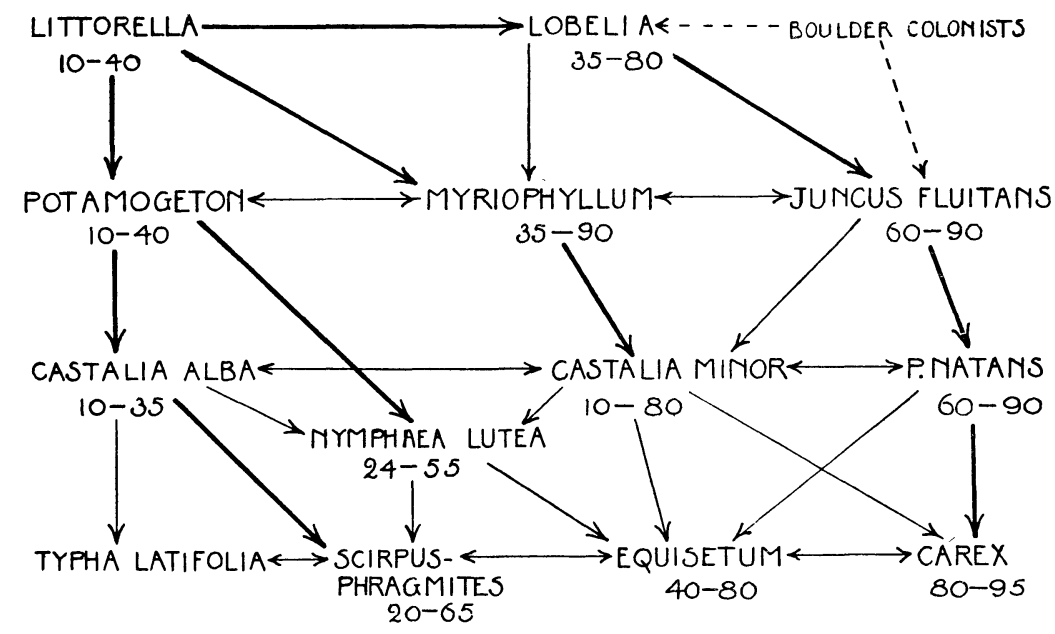

Rapid silting Moderate silking

Silking nearly absent.

Fra. 13. Succession among shallow water communities, the figures indicating the percentage organic content or the soil.

Similarly, the earlier phases of each of these three lines of succession may be assumed to be caused by physiographic factors, since changes in plant communities are caused chiefly by increase in the abundance of sediments, 
with the chemical changes that this produces. It is, however, much less easy to distinguish the factors causing change in the later phases of these successions.

There are indications that the proportion of potash in the soil decreases during such successions, and that this decrease is accompanied by an accumulation of organic matter. Thus, while one sample of a $P$. alpinus soil contained only .022 per cent. of potash, an adjacent soil-under similar silting conditions - bearing $P$. prcelongus contained .041 per cent. potash. Similarly two soils on which $P$. obtusifolius was abundant contained less $\mathrm{K}_{2} \mathrm{O}$ than adjacent soils bearing Naias or $P$. pusillus. It is true that the proportions of potash to inorganic matter were almost identical in these instances, yet the fact remains that the concentration of potash is uniformly less in the more organic soils, a factor likely to be of great importance in determining the reaction of these soils to plants, particularly to the micro-organisms which determine the rate and type of organic decomposition.

Bearing on this point is the observation that the plants found on poorer soils often (not generally) succeed those found on richer soils as the organic content increases,

e.g. $P$. praelongus or linear-leaved associes $\rightarrow P$. perfoliatus, or it may be $P$. pusillus, perfoliatus or praelongus $\rightarrow$ Nitella, whose chief requisite is apparently a soft substratum.

It is quite certain, however, that the organic and potash contents of the soil are not the only factors in operation, for if this were so the change $P$. praelongus $\rightarrow P$. alpinus would be reversible, which is, apparently, not the case. On the other hand, changes like Nitella $\rightleftharpoons P$. praelongus are truly reversible, as are most of those where the change is caused by an increase in the abundance or richness of silts, though the elimination of Isoetes appears to be an exception to this generalisation. Thus it seems possible to conclude that changes caused by silting factors are usually reversible, while changes accompanied by a marked increase in soil organic content are normally irreversible, and must therefore be assumed to depend on some soil change independent of the inorganic constituents.

In support of this suggestion it may be urged that the appearance of the more organic soils changes as succession advances. They become more fibrous (i.e. less completely decayed) and yellow or brown in colour rather than grey or black. Moreover, reference has already been made to the peculiar soil type upon which Sparganium minimum occurs, and in this instance one has to assume that the soil will not permit the growth of other submerged plants.

These observations seem to justify the following assumption, that as succession advances, organic matter accumulates more rapidly than silts, and that products appear which prevent the re-development of earlier plant communities. In the more fertile soils, these changes present certain similarities to those resulting in the formation of "acid" soils, e.g. the increase in organic content and the decrease in the proportion of potash (? and bases) 
present. In the case of the coarser and poorer soils, the successional changes can be completely identified with the production of "acid" peat, as in the example Juncus fluitans $\rightarrow$ P. natans.

\section{Shaliow Water Communities.}

This group of plant communities shows in many respects the most interesting, and at the same time the most complex, relations with the habitat. While deep water plants can be chiefly connected with the type of silt deposited on their habitats and with its relative abundance, shallow water plants are also directly affected by wave action, and grow on soils in which organic matter is generally more abundant. While plant remains cannot accumulate where wave action is vigorous, owing to scarcity of vegetation, or where silt is rich and abundant (e.g. near slow streams), as a whole these habitats possess a higher organic content than do those found in deep water--a result of almost ceaseless water movement, and consequent removal of silts. It follows also that silts, if deposited, tend to be coarse, and poor in potash. Thus the mean of four samples gave a potash content in this zone of only $\cdot 022$ per cent. (range $\cdot 015-029)$, a feature to be correlated with the ligher organic content, and coarser sediments.

Upon these factors the nature of the vegetation depends. Very striking is the scarcity of Potamogeton spp. and of water-lilies, due to the paucity of the substratum and the strength of wave action. On the whole, silts, Potamogeton and water-lilies occur only near the mouths of streams, or in other well sheltered and silted places (see Figs. 6, 8 and 9).

Colonisation is normally begun by Littorella uniflora Asch., which, by reason of its vegetative propagation, can spread over and stabilise loose sand, gravel or morainic stones. Rocks and boulders are usually quite without Littorella, and wave action, by pulverising the shore and providing fine materials, seems to be a necessary precursor of plant colonisation, unless fluvial silts are abundant and wave action very slight. Littorella is, therefore, less frequent in the more rocky lakes, whose shores are, on the whole, little altered by wave action, but Isoetes, Lobelia Dortmanna L. and Juncus fuitans may also occur in a colonising rôle in this type of lake, provided the substratum is stable. Granitic gravel appears to be particularly suitable for the latter species, but since they appear to be unable to cope with shifting sand or gravel (or with the finer and richer sediments) they play a subordinate part in the colonisation of the typical shores. The tough and apparently sterile boulder clays, occasionally found on sheltered shores, are also colonised primarily by scattered families of Isoetes. Generally, however, Littorella, by forming a continuous sward over the shifting substratum, collects sand and probably seeds, and is followed by a further development of shore communities.

The most convenient way of considering the changes which result is to 
arrange the communities found in order of their soil organic content, a factor to which we can roughly relate the other variables of the habitat, wave action and silting.

The organic content of the Littorella consocies ranges from 2-90 per cent., but Littorella is entirely dominant only between 10-40 per cent. and rarely sub-dominant where the percentage exceeds 60 .

Lobelia Dortmanna L., on the other hand, only becomes sub-dominant when the organic content is between $35-80$ per cent., its total range when abundant being 10-98 per cent. Thus, as the soil becomes more organic, Lobelia appears and tends to replace Littorella.

In bays, therefore, where the community is well advanced and where wave action is least, Lobelia is normally abundant and the soil relatively organic. On the other hand, where silts are abundant, as near streams or where erosion is vigorous, the substratum tends to be inorganic, and Littorella is quite dominant.

At a later stage when, if anything, fine sand and silt, not gravel, are deposited on the substratum, other communities appear.
i. Potamogeton assogies. Av. organic content of soil $22.2 \%$, range 5-40\%.
ji. Myriophyllum consocies. " " $\quad$, $42.7 \%, \quad, 20-65 \%$.
iii. Juncus fluitans socies. $\quad$ " $\quad$ " $86.6 \%, \quad$ "60-96\%.

The Potamogeton associes may be composed of one of the following species:
$P$. gramineus L.
and var. longipedunculata (Merat.)
$P$. angustifolius Presl.
$P$. nitens var. subgramineus Raunk.
$P$. perfoliatus $\mathrm{L}$.
$P$. alpinus Balb.

Of these, $P$. perfoliatus and $P$. alpinus persist when the organic content of the soil is over 40 per cent. Except $P$. gramineus, these plants rarely produce floating leaves, and cannot be regarded as early stages of the floating leaved growth form. They occur in very local clamps, the $P$. gramineus group usually on sand behind a wave-formed spit (see Figs. 6 and 11). The actual growth form found in such a place apparently depends on the degree of exposure, and therefore the common form is a dense mass of slender vegetative shoots along the ground, with occasional almost leafless peduncles rising to the surface of the water ${ }^{1}$. In greater shelter, more typical $P$. gramineus or $\times P$. nitens is occasionally found. Near the mouth of a slow stream, the $P$.gramineus group is absent, and the other three species occur. In all cases, silting is rapid and the water is usually over $1 \mathrm{~m}$. deep. This associes is absent from the rocky lakes, and only occasional elsewhere. (Figures 8 and 9.)

The Myriophyllum consocies is common where Littorella is well established, particularly near small streams, or to the lee of woods, in which places the lake floor often becomes carpeted with dead leaves and twigs. The community more often forms a line along the shore, about the base of the wave cut terrace.

1 . gramineus var. longipedunculata Merat., and $\times P$. nitens, var. subgramineus Raunk. $f$. stenobasis (Hagstr.). 


\section{The Aquatic Vegetation of the English Lakes}

This position probably is the earliest part of the shallow water to be colonised, and hence in later stages is more organic. A similar condition occurs on extensive shallows, where wave action is exhausted on the outer edge and Littorella is early developed on the inner parts. In such places, Myriophyllum is abundant. $M$. spicatum $\mathrm{L}$. is the most frequent species, but is replaced by M. alterniflorum D.C. in Esthwaite. M. verticillatum L. (r) and Ranunculus peltatus Schr. var. truncatus Koch (la) also occur.

The Juncus fluitans socies is less common and only occurs where the soil is more or less peaty, Juncus being usually abundant or sub-dominant. Lobelia is more abundant than Littorella, owing to the high organic content of the soil, and there are always signs of the development of reed swamps or floating leaved plants, the community being essentially transitional. Associated with the dominant plants are, Apium inundatum R.f. (1), Scirpus fluitans L. (o), Utricularia neglecta Lehm. f. gigantea Prahl. (la), Sparganium minimum Fr. (f), Nitella opaca Ag. (o), Isoetes lacustris L. (r), while Myrinphyllum (f-o) and Ranunculus sp. (o) are probably vestigial.

It is noteworthy that while communities in this late stage of development are absent from rocky lakes, the families of Juncus fluitans, Isoetes and Lobclia found in such lakes, suggest that the Juncus socies may arise in two ways, (1) from the bare rock colonists named above, (2) from the Littorella sward on cessation of silting.

The essential fact that emerges from this discussion is that in later stages of the Littorella-Lobelia associes we have a series of plant groupings, merging into one another and often indistinct, but depending on the organic content of the substratum, itself a function of the rate of silting. At one end of this series is the Littorella-Potamogeton type, inorganic and relatively potash-rich, at the other end, the Lobelia-J. fuitans transitional type, organic and potashpoor. Thus the relation between the subordinate species of Potamogeton and Juncus is essentially that shown by the deep water consocies of these plants.

Floating leaved Communities can be regarded in an exactly similar manner in relation to the organic content and silting conditions of their habitat. The series would then read:

1. Castalia alba consocies-average organic content of soil: $25 \cdot 7 \%$, range $10-35 \%$.

2. Nymphaea lutea " " " $\quad 38.6 \%, \quad$ "24-55\%.

3. Castalia minor $\quad$ " $\quad$ " $\quad 48.5 \%, \quad, \quad 10-75 \%$.

4. Potamogeton natans,$\quad$, $\quad$, $\quad 74 \cdot 2 \%, \quad, \quad 60-92 \%$.

Complications occur here, however, from the direct effects of wave action, which limit this type of community to the most sheltered places. Where exposure is greater, Castalia minor D.C. and Nymphaea intermedia Ledeb. tend to replace Castalia alba Wood. and $N$. lutea L., even though the substrata are relatively inorganic. Probably there are also corresponding edaphic differences, e.g. coarser sediments and lower potash content, for these two forms overlap with the Potamogeton natans consocies, and generally, though not always, the 
organic content of the soil is also high. The chemical differences between the two main types of substratum in shallow water can be gathered from the figures given below, from two adjacent bays in Windermere. One of these contained $P$. natans and Juncus fluitans, the other, Nymphaea lutea and Potamogeton alpinus (sd), with Castalia alba (f), on a soil heavily silted from an inflowing stream. (Figures in parts per million.)

$\begin{array}{lccccc}\text { Organic } & & & & \\ \text { content } & \mathrm{K}_{2} \mathrm{O} & \mathrm{CaO} & \mathrm{NO}_{3} & \mathrm{PO}_{4} \\ \text { P. natans-J. fluitans on dark close peat } & 68.0 \% & \mathbf{1 5 3} & 620 & \cdot 68 & 10 \\ \text { Nymphaea-P. alpinus on light open silt } & 43.5 \% & \mathbf{2 1 0} & 630 & .80 & 20\end{array}$

Thus the silted type of substratum is characterised by higher potash content, and lower organic content, the latter being correlated with a higher rate of decay.

Floating leaved plants are usually very local in these lakes, owing to continual wave action along the shores, which prevents the accumulating of sediments. Only Esthwaite, smaller and rich in silts, has large areas of waterlilies. As a contrast, Derwentwater, also small and with many sheltered bays, may be noticed. Here, silts being relatively scarce, $P$. natans $\mathrm{L}$. is the characteristic floating leaved plant, except very locally near the mouths of streams, where water-lilies are also found. (Figures 8 and 9.) On the whole, this is the condition found in the majority of the lakes.

Reedswamp communities show the same general relation to the organic content of the substratum, and to silting, but in a less definite way, for the vigorous perennial habit of the species enables them to persist in spite of changing conditions, and owing to the mass of rhizomes and superficial débris, the accurate sampling of the soil is a matter of great difficulty.

1. Typha latifolia consocies

2. Scirpus-Phragmites associes

3. Equisetum limosum consocies

4. Carex spp. associes

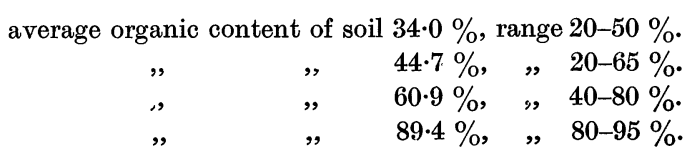

Typha latifolia L. occurs only round the mouth of the main affluent at Esthwaite, a place characterised by abundant fine silt, and rapid change of soil level. Marsh gas is liberated in great abundance on disturbing the soil, and this probably indicates a very rapid decomposition of soil organic matter.

Phragmites vulgaris. Trin. and Scirpus lacustris L. form the characteristic reedswamps of most lakes, but are still very local, owing to the hardness or instability of most shores. Scirpus, as is usual elsewhere, occurs in deeper water and also shows a preference for more organic substrata. This reedswamp associes is found in open bays; where there is slight wave action, and hence a certain amount of silting. Sheltered western shores, the mouths of streams, and extensive shallows also often support Scirpus-Phragmites communities.

Closed bays and profoundly sheltered shores tend, on the other hand, to lack both wave erosion and affluents, and to have reedswamps of Equisetum

Journal of Ecology VIII 
limosum L. and Carex spp. (see Figs. 8, 9 and 10). This type of reedswamp is therefore also characteristic of the more rocky lakes, and is rarer in the silted lakes, e.g. Esthwaite.

Carex inflata Huds. and Carex vesicaria L. are the characteristic species of this type of reedswamp, but C. lasiocarpa Ehrh. (la) and C. inflata $\times$ vesicaria also occur.

As a whole, the floating leaved and reedswamp communities are usually closed and nearly pure communities of the dominant plants, but very commonly this group originates in an open reedswamp containing a large number of species-a mictium (cf. Tansley, 16). Besides the species already mentioned as characteristic of shallow water, the following also occur in this type of mictium:

$\begin{array}{llll}\text { Sparganium natans } \text { L. } & \text { la } & & \text { Utricularia neglecta } \text { Lehm. la } \\ \text { Apium inundatum } \text { R. f. } & \text { la } & & \text { Callitriche intermedia } \text { Hoffm. o } \\ \text { Scirpus fluitans } \text { L. } & \text { o } & \text { C. stagnalis } \text { Scop. } & \text { r }\end{array}$

Sparganium natans characterises relatively inorganic soils, Utricularia peaty places, while Apium is intermediate between these extremes. The dominant plants in such a mictium occur in the habitat conditions already described. Thus the mictium as a whole is not only a "transitional mixture between successive seral dominants" but also a mixture of plants characterising different types of succession (see below).

Succession. There are, it is clear from the above, two main types of plant succession, depending on the rate of silting and the consequent organic content of the soil.

Where silting is rapid and the substrata inorganic, we get the silted type:

Littorella $\rightarrow$ Potamogeton $\rightarrow$ water-lily $\rightarrow$ Phragmites.

Where silt is scarce and the soil organic, the peaty type is found:

$$
\text { Lobelia } \rightarrow \text { Myriophyllum } \rightarrow \text { P.natans } \rightarrow\left\{\begin{array}{l}
\text { Equisetum } \\
\text { Carex. }
\end{array}\right.
$$

Actual observation shows that the types of succession are very numerous, and the more important transitions observed are indicated in Fig. 13. In the majority of cases, intermediate and varying conditions of silting exist. It commonly happens that a habitat, at first heavily silted, becomes later only lightly silted, and finally, perhaps, entirely free from silt owing to the formation of spits or banks, which cut off the source of silt. Another previously unsilted habitat will, at the same time, become rapidly silted. In the former case, the general line of plant succession would be Littorella $\rightarrow$ Carex, in the latter case, it would be Lobelia $\rightarrow$ Phragmites, the actual direction of change depending in each case on the actual change in the rate of silting. Some of the more definite of these subordinate lines of succession are indicated in the figure by fainter arrows.

It does not follow, however, that any community may pass into any other. The appearance of floating leaved or of reedswamp plants apparently marks 
an irreversible change in habitat. On the other hand, changes between communities of the same level (e.g. different floating leaved communities) are apparently reversible, the changes being dependent on the rate and type of silting. Thus as silt decreases, Castalia alba may be replaced by C. minor and this by Potamogeton natans; as silt became more abundant, the reverse would be the case. Similarly, we find:

$$
\begin{aligned}
\text { Potamogeton socies } & \rightleftharpoons \text { Myriophyllum } \\
\text { Phragmites } & \rightleftharpoons \text { Iuncus fluitans, or } \\
\rightleftharpoons \text { Equisetum } & \rightleftharpoons \text { C'arex, }
\end{aligned}
$$

depending on changes in silting.

The prime effect of plant growth on the soil is to increase the organic content, and hence as a succession progresses, organic matter tends to accumulate, unless silting is very rapid. This tendency is very marked in the case of floating leaved and reedswamp communities, chiefly because they impede the movement of water (and silt) and deposit large quantities of organic matter. Hence the proportion of potash tends to decrease as organic content increases:

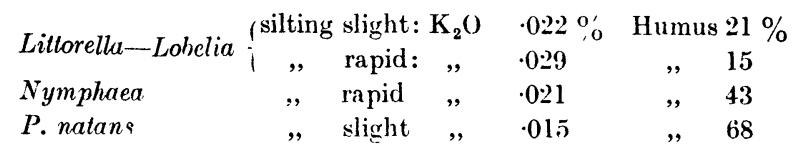

It seems probable that this tendency would be still more marked in the interior of reedswamps, where silt-bearing waters can penetrate less easily.

The absence of water movement also causes a considerable change in temperature conditions, as is shown by the following comparative figures (August, 1919).

$\begin{array}{lcccc}\text { Depths in metres } & 2 \cdot 0 & 1 \cdot 0 & .7 & \cdot 5 \\ \text { Plants dominant } & \text { Littorella } & \text { P. Zizii } & \text { Nymphaea } & \text { Phragmites } \\ \text { Water temp. }{ }^{\circ} \mathrm{C} . & 14 \cdot 5 & 15 \cdot 0 & 17 \cdot 9 & 17 \cdot 0 \\ \text { Soil temp. }{ }^{\circ} \mathrm{C} . & 15 \cdot 0 & 15 \cdot 0 & 20 \cdot 1 & 18 \cdot 2 \\ & & & & \\ \text { Depth in metres } & 1 \cdot 2 & \cdot 7 & \cdot 4 & \\ \text { Plants dominant } & \text { Littorella } & \text { J. fluituns } & \text { Equisetum } & \\ & \text { Lobelia } & \text { P. natans } & & \\ \text { Water temp. }{ }^{\circ} \mathrm{C} . & 15 \cdot 1 & 22 \cdot 0 & 20 \cdot 2 & \\ \text { Soil temp. }{ }^{\circ} \mathrm{C} . & 16.0 & 26 \cdot 6 & 21 \cdot 0 & \end{array}$

Thus the temperature conditions get more favourable as the succession progresses-but it is clear that the change is a result rather than a cause of the change in plant community. Thus the greater shade of the reedswamp causes a fall in temperature.

It is interesting to inquire further into the cause of these plant successions so far as the limited data will allow. Such an inquiry leads to the tentative conclusion that succession is chiefly a result of changes in the amount and nature of the soil organic compounds. In the first place, observation alone, crude test though it be, shows that even when the rate of silting is high and the soil organic content is nearly constant, different plant communities 
are associated with soils of different appearance. Thus Littorella mud is usually blue black, that from among water-lilies yellow-brown and loose, whilst mud beneath Phragmites is dark brown or black and somewhat peaty.

Secondly, almost sterile areas of high organic content are not uncommon, preceding the advent of water-lilies, or at times, of reeds. (The Sparganium minimum consocies characterises areas of a similar type.) These suggest that the character of the soil has so changed as to be ursuitable (? toxic), to the plants which contributed the organic matter. Since such areas are colonised by water-lilies or reeds, it is clear that these soils are not unsuitable to plants of succeeding communities.

Finally, it has been shown that organic matter tends to accumulate and that this probably results in a decrease in the proportion of $\mathrm{K}_{2} \mathrm{O}$ (and bases?). In other words there is probably a tendency for the soil to become increasingly unsaturated (adsorptively) that is, relatively "acid." This tendency is only prevented by the deposition of silts, and if organic matter is allowed to accumulate unchecked, it results in the appearance of moorland types of vegetation, e.g. Castalia minor, P. natans, Equisetum and Carex spp. and is often, though perhaps not always, accompanied by a high concentration of $\mathrm{CO}_{2}$ in the water.

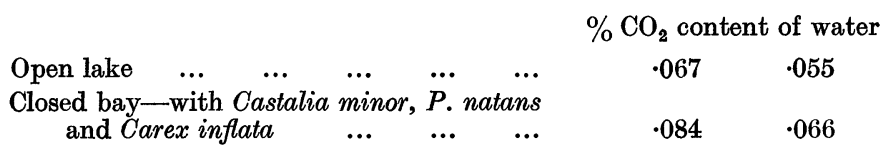

See also Bergmann (1), and Birge and Juday (2) who obtained similar results.

Soils underlying this type of vegetation are relatively peaty and undecayed as contrasted with the fen or amorphous type of peat, which is undergoing silting and which evolves large quantities of gas when disturbed, a fact probably indicating rapid decay.

Moreover, the quantity of organic matter deposited per annum, is much greater in the cases of the large Potamogeton spp., water-lilies, or Phragmites types than for Juncus fluitans, P. natans, or Equisetum and Carex. The fact that the soils on which the former grow, still remain relatively inorganic, therefore indicates a more rapid rate of decay, since the amount of silt deposited must be small compared with the masses of vegetation.

A similar contrast has been suggested between the deep water soils of the Juncus fluitans community and those of the Potamogeton communities, the latter being characterised by amorphous organic matter. It seems clear that though there is an intimate connection between the silting factor and the type of soil produced, plant succession depends more upon the amount and nature of the soil organic matter, and it seems particularly important to emphasise the point that changes in plant community can-both for plants 
on the coarser, deep water silts and for the shallow water peaty types of vegetation-be identified with the production of moorland types of soil.

A similar phenomenon is shown by the more fertile soils: as succession advances, they become more organic and poorer in potash. Though owing to the influence of continued silting, their reaction is never so extreme as in the poorer types, in this case also the changes apparently causing plant succession are those leading to the production of "acid" soils.

\title{
SumMary.
}

The evidence presented in the preceding pages from the study of the aquatic plant communities of the English Lakes, seems to justify certain general conclusions for this lake area:

(1) The distribution of the aquatic plants considered is primarily governed by the nature of the substratum, while the reaction of the substratum to vegetation is controlled by variations in the quality and quantity of sediments deposited on it and by the type and quantity of organic matter it contains.

(2) Light intensity may limit the depth to which types of vegetation descend, but is of secondary importance as a factor in the distribution of most of the plants considered.

(3) Temperature conditions are assumed to retard the development of vegetation during early summer, but in other respects to be of little significance.

(4) The absence of free floating vegetation is attributed to the paucity of the waters in essential plant food substances.

(5) Plant succession is accompanied by changes in the substratum akin to those resulting in the formation of moor peat.

\author{
Botany Department, \\ The University of Leeds.
}




\section{APPENDIX I}

\section{Water Analyses of English Lake Waters.}

Figures in parts per million.

I)issolved Solids

\begin{tabular}{|c|c|c|c|c|c|c|c|c|c|c|c|c|}
\hline 1. Wastwater & $\underset{42.8}{\stackrel{0}{*}}$ & $\begin{array}{l}5 \\
4 \cdot 3\end{array}$ & $\begin{array}{c}38.5 \\
\end{array}$ & $\begin{array}{c}\mathrm{K}_{2} \mathrm{O} \\
13 \cdot 1\end{array}$ & $\begin{array}{r}\mathrm{CaO} \\
2 \cdot 4\end{array}$ & $\begin{array}{c}\mathrm{MgO} \\
1 \cdot 8\end{array}$ & $\begin{array}{c}\mathrm{Al}_{2} \mathrm{O}_{3} \\
\text { tr. }\end{array}$ & $\begin{array}{l}\mathrm{CO}_{3} \\
3 \cdot 9\end{array}$ & $\begin{array}{c}\mathrm{SO}_{3} \\
10 \cdot 1\end{array}$ & $\begin{array}{c}\left({ }_{2}\right. \\
5 \cdot 7\end{array}$ & $\begin{array}{l}\mathrm{SiO}_{2} \\
1 \cdot 4\end{array}$ & $\begin{array}{l}\mathrm{NO} \\
-\end{array}$ \\
\hline 2. Ennerdale & $30 \cdot 6$ & $5 \cdot 6$ & $25 \cdot 0$ & $7 \cdot 3$ & $2 \cdot 4$ & $1 \cdot 2$ & tr. & $2 \cdot 4$ & $4 \cdot 6$ & $5 \cdot 7$ & $1 \cdot 4$ & \\
\hline 3. Buttermere & $52 \cdot 5$ & $6 \cdot 4$ & $46 \cdot 1$ & $15 \cdot 4$ & $2 \cdot 8$ & $2 \cdot 3$ & $0 \cdot 4$ & $3 \cdot 2$ & $33 \cdot 9$ & $6 \cdot 6$ & $1 \cdot 4$ & \\
\hline 4. Crummock & $66 \cdot 5$ & $8 \cdot 0$ & $58 \cdot 5$ & $15 \cdot 2$ & $4 \cdot 0$ & $2 \cdot 6$ & $1 \cdot 3$ & $2 \cdot 4$ & $24 \cdot 4$ & $7 \cdot 1$ & $1 \cdot 4$ & \\
\hline 5. Hawes Water & $47 \cdot 1$ & $4 \cdot 3$ & $42 \cdot 8$ & $12 \cdot 3$ & $4 \cdot 0$ & $3 \cdot 6$ & $0 \cdot 1$ & $7 \cdot 1$ & $5 \cdot 7$ & $7 \cdot 1$ & $2 \cdot 8$ & r. \\
\hline 6. Derwentwater & $49 \cdot 9$ & $2 \cdot 4$ & $47 \cdot 5$ & $7 \cdot 7$ & $9 \cdot 5$ & $1 \cdot 5$ & 0.7 & $3 \cdot 1$ & $11 \cdot 4$ & 11.9 & $2 \cdot 1$ & \\
\hline 7. Bassenthwaite & $57 \cdot 0$ & $6 \cdot 1$ & $50 \cdot 9$ & $8 \cdot 3$ & $7 \cdot 9$ & $3 \cdot 5$ & $0 \cdot 4$ & $5 \cdot 7$ & $14 \cdot 9$ & $7 \cdot 1$ & $2 \cdot 8$ & $0 \cdot 4$ \\
\hline 8. Coniston & $49 \cdot 9$ & $7 \cdot 1$ & $42 \cdot 8$ & $11 \cdot 2$ & $4 \cdot 8$ & $4 \cdot 3$ & $0 \cdot 3$ & $8 \cdot 5$ & $2 \cdot 2$ & $8 \cdot 6$ & $2 \cdot 8$ & 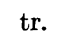 \\
\hline 9. Windermere & $59 \cdot 8$ & $10 \cdot 8$ & $49 \cdot 0$ & $5 \cdot 4$ & $10 \cdot 1$ & $1 \cdot 4$ & 0.4 & $6 \cdot 4$ & $13 \cdot 1$ & $8 \cdot 5$ & $3 \cdot 3$ & $2 \cdot 0$ \\
\hline 0. Ullswater & $54 \cdot 2$ & $11 \cdot 4$ & $42 \cdot 8$ & $10 \cdot 6$ & $5 \cdot 6$ & $3 \cdot 1$ & $0 \cdot 1$ & $7 \cdot 8$ & $4 \cdot 2$ & $7 \cdot 1$ & $4 \cdot 3$ & $2 \cdot 0$ \\
\hline 1. Esthwaite & $75 \cdot 9$ & $13 \cdot 8$ & $62 \cdot 1$ & $10 \cdot 4$ & $9 \cdot 5$ & $5 \cdot 1$ & 0.7 & $7 \cdot 6$ & $18 \cdot 7$ & $8 \cdot 6$ & $3 \cdot 0$ & $2 \cdot 3$ \\
\hline 2. Thirlmere* & $51 \cdot 5$ & $11 \cdot 0$ & $40 \cdot 5$ & $4 \cdot 9$ & $4 \cdot 3$ & $1 \cdot 2$ & & $10 \cdot 9$ & $7 \cdot 5$ & $11 \cdot 0$ & 0.7 & \\
\hline Mean & & 3 & $45 \cdot 3$ & $10 \cdot 6$ & $5 \cdot 7$ & $2 \cdot 8$ & 0.5 & $5 \cdot 2$ & $11 \cdot 2$ & $7 \cdot 6$ & $2 \cdot 4$ & $0 \cdot \mathrm{t}-2 x-3$ \\
\hline
\end{tabular}

* The figures for Thirlmere are those of Hull, Geol. Mag. 1893, p. 171. As they are not figures for the period 1913-1920, they are omitted in obtaining the mean, but they show the same characteristics as the other samples.

\section{APPENDIX II}

\section{Percentage Organic Content of Solls.}

Deep water types.

Plant community

Isoetes

Nitella

Juncus fluitans

Potamogeton pusillus

P. perfoliatus

P. praelongus

P. alpinus

P. obtusifolius

Sparganium minimum
$2 \cdot 7,5 \cdot 0,13 \cdot 2,17 \cdot 3,21 \cdot 0,25 \cdot 7,49 \cdot 4,66 \cdot 6$

$8 \cdot 4,9 \cdot 0,11 \cdot 3,15 \cdot 8,16 \cdot 0,16 \cdot 9,17 \cdot 5,18 \cdot 3,26 \cdot 4,29 \cdot 0,34 \cdot 6$

$17 \cdot 5,21 \cdot 0,25 \cdot 3,30 \cdot 0,32 \cdot 3,35 \cdot 2$

$12 \cdot 1,13 \cdot 2,13 \cdot 7,13 \cdot 9,14 \cdot 6,14 \cdot 9,16 \cdot 3,17 \cdot 0,19 \cdot 1,21 \cdot 0,25 \cdot 3$

$13 \cdot 2,18 \cdot 1,21 \cdot 0,28 \cdot 9$

$10 \cdot 0,12 \cdot 7,15 \cdot 6,21 \cdot 0$

$21 \cdot 0,32 \cdot 0,37 \cdot 1,43 \cdot 5$

$21 \cdot 3,22 \cdot 0,23 \cdot 6,15 \cdot 7,18 \cdot 9$

$24 \cdot 6,43 \cdot 6,55 \cdot 3,95 \cdot 4$
Range Mean $2-7025 \cdot 0$ 8-35 $18 \cdot 4$ $17-35 \quad 26 \cdot 9$ 12-25 $16 \cdot 4$ $\begin{array}{ll}13-30 & 20 \cdot 3\end{array}$ $\begin{array}{ll}10-21 & 14 \cdot 8\end{array}$ $20-45 \quad 33 \cdot 4$ 15-25 $20 \cdot 3$ 24-95 $44 \cdot 7$

5-40 $22 \cdot 8$ 60-92 $42 \cdot 6$ 15-95 $55 \cdot 6$ 20-65 $42 \cdot 7$ 60-96 $81 \cdot 8$ $\begin{array}{lll}10-40 & 25 \cdot 4\end{array}$ 10-35 $25 \cdot 7$ 24-55 38.6 10-80 48.5 60-92 $74 \cdot 2$ 25-65 $44 \cdot 7$ 40-80 60.9 80-95 89.4 


\section{REFERENCES}

(1) Bergmann, H. F. "The Relation of Aeration to the Growth and Activity of Roots, etc." Ann. Bot. 34, 1920.

(2) Birge, F. A. and Juday, G. "Inland Lakes of Wisconsin-The Dissolved Gases and their Biological Significance." Wisc. Geol. and Nat. Hist. Surv. 32, 1911.

(3) Bronsted and Wesenburg-Lund, C. "Chemisch. phys. Untersuchungen der Dänischen Gewässe." Intern. Rev. 6, 1912.

(4) Brown, W. H. "The Relation of the Substratum to the Growth of Elodea." Contrib. U.S. Nat. Herb. 13.

(5) Cameron, F. K. The Soil Solution (Chemical Publ. Co.) Easton, Pa., 1916.

(6) Clements, F. F. Plant Succession. Carnegie Inst. Washington. 1916.

(7) Hutchings, G. "On the Sediments from English Lakes." Geol. Mag. 1894.

(8) Kindle, F. M. "A new. Bathymetric Record for Attached Algae and Diatoms in L. Ontario." Journ. Ecol. 3, 1915.

(9) Magnin, A. "Végétation des Lacs du Jura." Rev. Gén. de Bot. 5, 1893.

(10) Mill, H. R. "Bathymetrical Survey of the English Lakes." Geog. Journ. (London), 6, 1895 .

(11) Murray, Sir John and Pullar, L. Bathymetrical Survey of the Fresh-water Lochs of Scotland, 1 (Edinburgh), 1910.

(12) Pearsall, W. H. "The Aquatic and Marsh Vegetation of Esthwaite Water." Journ. Ecol. 5, 1917 and 6, 1918.

(13) _ "On the Classification of Aquatic Plant Communities." Journ. Ecol. 6, 1918.

(14) Russell, E. J. Soil Conditions and Plant Growth. London, 1917.

(15) Soret, J. L. "On the Colour of Lake Geneva." Phil. Mag. (London), N.S. 37, 1869.

(16) Tansley, A. G. "The Development of Vegetation" (Review). Journ. Ecol. 4, 1916.

(17) Wedderburn, F. M. "The Temperature of Scottish Lakes." Scot. Bath. Survey, 1 (Edinb.), 1910.

(18) West,. G. "A Comparative Study of the Dominant Phanerogamic and Higher Cryptogamic Flora of Aquatic Habit in three Lake areas of Scotland." Proc. Roy. Soc. Edinb. 25, 1905 and 30, 1909.

(19) West, W. and G. S. "On the Periodicity of the Phytoplankton of some British Lakes." Journ. Linn. Soc. (Bot.), 40, 1912. 